Josip VUČKOVIĆ

Staroslavenski institut

Zagreb

josip.vuckovic@stin.hr
UDK 821.163.42-9“"14“.09

$2-57(33)(036)$ “" 14 “"

$003.349(497.5)$ " 14 “

Izvorni znanstveni članak

Primljen: 14. srpnja 2017.

Prihvaćen: 20. rujna 2017.

\title{
SREDNJOVJEKOVNI ITINERAR PO SVETOJ ZEMLJI IZ VINODOLSKOGA ZBORNIKA
}

U članku se objavljuju prva povijesna i književnopovijesna analiza te transliteracija kasnosrednjovjekovnoga teksta ot er(u)s(o)l(i)ma i groba b(o)žiê čt(enie) koji je zapisan u Vinodolskom zborniku (Zagreb: Arhiv HAZU, sign. III a 15). Posrijedi je jedini zasad poznati hrvatski srednjovjekovni itinerar po Svetoj zemlji, koji je vjerojatno bio sastavljen na temelju nepoznata latinskoga ili romanskoga teksta. Obrazlaže se hipoteza prema kojoj hrvatskoglagoljski itinerar nije bio zamišljen kao praktičan hodočasnički vodič, nego kao poučan tekst namijenjen učvršćivanju »kolektivnoga pamćenja « o Svetoj zemlji kao prostoru na koji kršćani imaju isključivo pravo. Osim toga, iznosi se hipoteza da je hrvatskoglagoljski itinerar mogao biti namijenjen razmatranju povijesti Spasenja u obliku virtualnoga hodočašća.

Ključne riječi: Vinodolski zbornik, srednjovjekovni itinerar, hrvatskoglagoljska književnost, hodočašće, virtualno hodočašće, srednjovjekovni Jeruzalem, Sveta zemlja, kolektivno pamćenje, iterologija

\section{USTROJ, JEZIK, MJESTO I VRIJEME NASTANKA VINODOLSKOGA ZBORNIKA}

U ovom se radu objavljuju transliteracija te povijesno i književnopovijesno kontekstualiziran opis sadržaja hrvatskoglagoljskoga srednjovjekovnoga itinerara po hodočasničkim odredištima u Svetoj zemlji u kojemu se mjestimice govori i o udaljenostima među susljednim odredištima i njihovu relativnom položaju u prostoru. ${ }^{1}$ Riječ je o tekstu koji započinje incipitom

\footnotetext{
1 Važnije zaključke ovoga rada prethodno sam izložio u neobjavljenome referatu Hrvatskoglagoljski srednjovjekovni vodič po Svetoj zemlji s Međunarodnoga znanstvenog skupa Fenomen glagoljice koji se je 12. i 13. svibnja 2017. održao u Biogradu i Zadru.
} 
ot er(u)s(o)l(i)ma i groba b(o)žiê čtt(enie) - k(a)p(i)t(ulb) (CVinod, f. 15ra) i nalazi se na listovima ff. $15 \mathrm{r}^{\mathrm{a}}-17 \mathrm{r}^{\mathrm{a}}$ pergamentnoga glagoljskoga rukopisa koji je pohranjen u Arhivu HAZU sa signaturom III a 15 (usp. ŠTEFANIĆ 1970: 5-10). Taj je rukopis među filolozima i povjesničarima hrvatskoga glagoljaštva poznat i pod tradicionalnim imenom Vinodolski zbornik. Ime toga zbornika povezano je s prostorom njegove uporabe u drugoj polovici 15. stoljeća, o čemu svjedoče vinodolskih onimi u tadašnjim potpisanim sekundarnim bilješkama (ŠTEFANIĆ 1970: 9-10). Međutim, već se u 17. stoljeću Vinodolski zbornik više nije upotrebljavao u Vinodolu, nego na otoku Krku, o čemu svjedoči niz potvrda vrbničkih i dobrinjskih onima u sekundarnim bilješkama iz toga vremena (ŠTEFANIĆ 1970: 10; usp. MILČETIĆ 1911: 214).

Budući da su kodeksi prenosivi predmeti, razumljivo je da se mjesto najranije posvjedočene uporabe Vinodolskoga zbornika ne mora nužno podudarati s mjestom na kojemu je taj zbornik nastao. Kolofoni srednjovjekovnih rukopisa u pravilu donose znatno pouzdanije podatke o mjestu i vremenu njihove proizvodnje nego bilješke na marginama, ali u Vinodolskome zborniku kolofona nema. Međutim, u slučaju Vinodolskoga zbornika ni potvrda kolofona ne bi nužno otklonila sve nedoumice oko mjesta njegova nastanka jer taj rukopis zapravo i nije jedinstvena »kodikološka jedinica« (codicological unit) (GUMBERT 2005). ${ }^{2}$ Naime, Vinodolski zbornik je konvolut koji je nastao fizičkim spajanjem sastavnica iz barem triju zasebnih kodeksa na kojima je radilo najmanje petero pisara (STROHAL 1916: 5; ŠTEFANIĆ 1970: 5, 10; usp. HERCIGONJA 1983: 344). ${ }^{3}$ Budući da je riječ o konvolutu, nameće se pitanje jesu li sve sastavnice Vinodolskoga zbornika nastale na jednome mjestu. Kada se Vjekoslav Štefanić suočio s pitanjem o podrijetlu pojedinih sastavnica sadašnjega kodeksa, napomenuo je da se u svim njegovim dijelovima ipak može

2 U hrvatskoj filologiji pojam »kodikološka jedinica« upotrebljava i Mateo Žagar (ŽAGAR 2007: 208), ali ne u istome značenju kao J. Peter Gumbert, čijim se terminom ovdje i u nastavku članka služim. Naime, Gumbert pojmom »kodikološka jedinica« (codicological unit) označava skup od jednoga ili više zajedno ukoričenih araka koji su ujedno bili i proizvedeni zajedno s namjerom da ih se učini dijelovima istoga kodeksa (GUMBERT 2005: 23, 25, 40). S druge strane, Žagaru je »kodikološka jedinica« opći naziv za tri razine na koje se može raščlaniti »trodimenzionaln[i] « ustroj kodeksa: »list«, »arak«, a »iz aspekta pisanja [...] i rastvoreni dvolist« (ŽAGAR 2007: 208).

3 Štefanićev zaključak da je Vinodolski zbornik nastao spajanjem više kodikoloških jedinica temelji se (A) na činjenici da se u različitim dijelovima toga kodeksa ponavljaju isti tekstovi, (B) na mjestimičnim ostatcima starije folijacije koja se ne podudara sa sadašnjom te (C) na gotovo nepostojećim marginama na listovima iz nekih dijelova zbornika, što je vjerojatno posljedica obrezivanja zaglavlja i (nešto rjeđe) podnožja tih listova s namjerom da se njihova visina prilagodi visini onih koje su izvorno pripadale kodeksu manjega formata (ŠTEFANIĆ 1970: 5, 10). 
uočiti visoka razina sličnosti u morfologiji slova, duktusu i pravopisnim rješenjima, što mu je onda poslužilo kao uporište za zaključak »da su sve ruke pisale otprilike $\mathrm{u}$ isto vrijeme $\mathrm{i} u$ istoj sredini« (ŠTEFANIĆ 1970: 5).

Polazeći od zaključka da su sve kodikološke jedinice u Vinodolskome zborniku ipak nastale u istome kraju i u kratkome intervalu, Štefanić je mjesto nastanka čitava kodeksa nastojao utvrditi na temelju jezika u njemu zapisanih tekstova. Pritom je osobitu važnost pripisao činjenici da uz prijepise redigiranih crkvenoslavenskih prijevoda i mlađe tekstove u kojima prevladavaju elementi književnoga jezika čakavske ili čakavsko-crkvenoslavenske stilizacije Vinodolski zbornik sadržava i veći broj čakavskih te čakavsko-crkvenoslavenskih tekstova koji su protkani i tipičnim kajkavizmima (ŠTEFANIĆ 1970: 5; usp. DAMJANOVIĆ 2008: 139, 143). ${ }^{4}$ Naime, pri sastavljanju kataloga glagoljske građe iz Akademijina arhivskoga fonda (ŠTEFANIĆ 1969.a; ŠTEFANIĆ 1970) Štefanić se prema pojavi tipično kajkavskih elemenata u jezično hibridnim glagoljskim rukopisima odnosio kao prema dosta pouzdanome pokazatelju da su ti rukopisi nastali na prostoru nekoga prijelaznoga ili sekundarno miješana čakavsko-kajkavskoga govora (usp. DAMJANOVIĆ 2008: 140-141; RADOŠEVIĆ 2016: 247). Primjenjujući takav interpretativni obrazac i na Vinodolski zbornik, Štefanić je ustvrdio da su njegove sastavnice napisane »negdje u užoj Hrvatskoj na granici čakavsko-kajkavskoj« (ŠTEFANIĆ 1970: 10; usp. HERCIGONJA 1983: 339).

Iako ne možemo isključiti mogućnost da je Štefanićeva tvrdnja o mjestu nastanka Vinodolskoga zbornika doista točna, upitno je može li se njezina točnost dokazati isključivo potvrdama kajkavizama u nekoliko zborničkih tekstova. Naime, određenu sumnju u pouzdanost dijalektološkoga pristupa utvrđivanju geografskoga podrijetla rukopisa u danome kontekstu unose već načelna Hercigonjina (HERCIGONJA 1983: 353) i Damjanovićeva (DAMJANOVIĆ 1995: 68; usp. DAMJANOVIĆ 2008: 146) razmišljanja o komunikacijskoj funkciji kajkavizama u jeziku hrvatskoglagoljske neliturgijske književnosti 15 . stoljeća. Naime, kroz njihove se radove provlači teza

4 Za prikaz sociolingvističkoga statusa spomenutih varijeteta vidi: MIHALJEVIĆ 2011: 231. Ne dovodeći u pitanje tvrdnju da se u Vinodolskome zborniku može prepoznati više »"sigurnih' kajkavizama«(DAMJANOVIĆ 1995: 75; usp. HERCIGONJA 1983: 311-313; DAMJANOVIĆ 2008: 161), Stjepan Damjanović na tragu Julija Derossija i Eduarda Hercigonje (DEROSSI 1975: 32-33; HERCIGONJA 1983: 353; usp. RADOŠEVIĆ 2016: 247) ipak upozorava da ponekad $»[n]$ ije [...] nimalo jednostavno odgovoriti na pitanje što u pojedinim povijesnim razdobljima možemo držati kajkavizmom i kako izbjeći nesumnjivoj opasnosti da nas zavede naš današnji jezični osjećaj « (DAMJANOVIĆ 1995: 68; usp. DAMJANOVIĆ 2008: 146). Za osvrt na propuste u dosadašnjim jezičnim analizama Vinodolskoga zbornika i poteškoće s kojima se suočavaju pokušaji da se odredi kojim su idiomom pojedini tekstovi pisani v. KAPETANOVIĆ 2016: 215-217. 
da se književna praksa tadašnjih glagoljaša uvelike vodila za načelom prema kojemu neliturgijske tekstove nije bilo dovoljno uskladiti s očekivanjima zavičajnih glagoljaša, nego su se tražile prilagodbe koje će ciljati na recipijente iz različitih društvenih slojeva te s nešto većega dijela hrvatskoga kulturnoga prostora (usp. RADOŠEVIĆ 2016: 247-248). Riječ je o načelu koje se prema Hercigonji i Damjanoviću najizrazitije očitovalo na jezičnoj razini, i to u voljnim pokušajima brojnih vernakularnih glagoljskih pisara da prekorače granice vlastitoga organskoga govora kako bi oblikovali potpuno nov književni idiom s odlikama čakavskih i kajkavskih govora (HERCIGONJA 2006: 225-226; DAMJANOVIĆ 2008: 141; usp. MIHALJEVIĆ 2011: 231), što ne znači da su ti pokušaji bili do kraja usustavljeni i koordinirani na razini čitave glagoljaške zajednice (usp. HERCIGONJA 1983: 355). Za razliku od Hercigonje koji je pretpostavljao da je spomenuta zamisao o naddijalektalnome hibridnome književnome jeziku u konačnici uglavnom dolazila do izražaja u radu glagoljaša koji su bili izravno povezani s pokupskim krajem gdje bismo kajkavske i čakavske elemente mogli očekivati i u organskim govorima (HERCIGONJA 1983: 339-352; HERCIGONJA 2006: 225), Damjanović je ipak prihvaćao mogućnost da je zamisao o hibridnome književnome jeziku bila toliko široko prihvaćena da su i glagoljaši s područja čistih čakavskih govora ponekad upotrebljavali tipično kajkavske jezične elemente s namjerom da uvećaju brojnost publike koja će biti otvorena za tekstove u njihovim rukopisima (DAMJANOVIĆ 2008: 141). Međutim, čak i ako se ne prihvati Damjanovićeva hipoteza da kajkavizmi u glagoljskim tekstovima nisu pojava koja se može isključivo povezivati s pokupskim krajem ili nekim drugim užim geografskim prostorom, Štefanićev pokušaj da na temelju potvrđenih kajkavizama utvrdi mjesto nastanka Vinodolskoga zbornika problematičan je već i stoga što je jezična heterogenost tekstova u tome kodeksu vrlo izražena. Naime, budući da i sam Štefanić ističe da »[j]ezik sastavaka nije jedinstven « (ŠTEFANIĆ 1970: 5), nije jasno zašto bi upravo tekstovi s kajkavizmima bili presudni za određivanje mjesta nastanka čitava konvoluta u okolnostima gdje takve elemente upotrebljavaju samo dvojica od pet pretpostavljenih pisara (usp. HERCIGONJA 1983: 344).

Što se tiče datacije Vinodolskoga zbornika, zasad je neupitan samo terminus ante quem za nastanak dijelova kojima pripadaju listovi ff. $37 \mathrm{r}-38 \mathrm{v}$ i ff. $64 \mathrm{v}-65 \mathrm{v}$. Naime, na tim se listovima nalazi niz izravno datiranih sekundarnih bilježaka među kojima su najstarije zapisane sredinom 15. stoljeća (usp. ŠTEFANIĆ 1970: 9-10). Individualne karakteristike pisarskih poteza različitih autora sekundarnih bilježaka upućuju na zaključak da najvjerojatnije nitko od njih nije sudjelovao u pisanju primarnih tekstova ni u kojoj od 
kodikoloških jedinica zbornika (ŠTEFANIĆ 1970: 9). ${ }^{5}$ Budući da primarni tekstovi i naknadne bilješke nemaju nijednu zajedničku pisarsku ruku, teško je reći koliko bi prvi tekstovi mogli biti stariji od drugih. Stoga se Štefanić u dataciji zbornika ponajprije oslonio na grafiju procjenjujući da »paleografski momenti govore za prvu polovicu ili sam početak XV stoljeća« (ŠTEFANIĆ 1970: 10; usp. MILČETIĆ 1911: 214). Ako se ta procjena naposljetku prihvati kao okvirno vrijeme pisanja svih triju kodikoloških jedinica iz Vinodolskoga zbornika, ostaje nejasno kada su te jedinice zapravo postale dijelovi jednoga kodeksa. Budući da je žakan Pilip, autor najstarije pouzdano datirane sekundarne bilješke iz 1450. godine (CVinod, f. 65r), ostavio još nekoliko takvih bilježaka na listovima dviju različitih kodikoloških jedinica (ŠTEFANIĆ 1970: 9-10), gotovo je sigurno da su se one sredinom 15. stoljeća upotrebljavale na istome mjestu. ${ }^{6}$ Ako su već tada te jedinice bile i uvezane zajedno, struktura tadašnjega kodeksa nije se nužno podudarala sa strukturom Vinodolskoga zbornika kakvim danas raspolažemo. Naime, okljaštrenost sekundarnih bilježaka pisanih na samim vrhovima pergamenata, među kojima jednu potpisuje i spomenuti žakan Pilip, otvara pitanje jesu li se možda i nakon sredine 15. stoljeća u strukturu kodeksa umetale nove kodikološke jedinice koje su imale manji format od pergamenata s djelomično odrezanim bilješkama (ŠTEFANIĆ 1970: 5, 9).

\section{STANJE ISTRAŽIVANJA TEKSTOVA IZ VINODOLSKOGA ZBORNIKA I ZNANSTVENA RECEPCIJA U NJEMU ZAPISANA ITINERARA}

Istraživači hrvatske srednjovjekovne glagoljske pismenosti i književnosti Vinodolskomu zborniku iz više razloga dodjeljuju važno mjesto među »zbornicima mlađega tipa s kraja XIV-XVI. stoljeća«, kako se u kroatistici nazivaju tadašnji »[n]eliturgijski rukopisi« u kojima su glagoljaši kompilirali ili prerađivali namjenski i sadržajno raznovrsne tekstove (HERCIGONJA 2009: 94; usp. HERCIGONJA 1975: 198-202; HERCIGONJA 2006: 218). U jezikoslovnoj kroatistici taj se zbornik osobito često spominje kao jedan od prvih pisanih izvora u kojima su potvrđeni kajkavizmi (ŠTEFANIĆ

5 Doduše, jednu nedatiranu potpisanu bilješku koja se nalazi na f. 65v Vinodolskoga zbornika (to pisa pop Ivanb z Ledenic b(og)b mu pomagai i s(ve)ta Mariê amenb) Strohal je pokušao povezati s jednom od ruku koje su prepisivale primarne tekstove u kodeksu (CVinod, f. 65v; STROHAL 1916: 5; usp. ZARADIJA KIŠ 2015.b: 127), ali je Štefanić njegovu atribuciju odbacio kao neutemeljenu (ŠTEFANIĆ 1970: 10).

6 Bilješke žakna Pilipa iz Drivenika nalaze se na ff. 38r, 64v, 65r, 65v, a možda i na f. $38 \mathrm{v}$ (ŠTEFANIĆ 1970: 9). 
1969.b: 29; HERCIGONJA 1983: 308; DAMJANOVIĆ 2008: 139), a nekoliko kraćih tekstova koji su pisani prestižnijim crkvenoslavenskim jezičnim registrom uključeno je i u korpus Rječnika crkvenoslavenskoga jezika hrvatske redakcije (usp. RJEČNIK 2000: xxxv). Među tekstolozima i povjesničarima hrvatske književnosti Vinodolski zbornik ponajprije je poznat kao izvor najstarijih potvrda hrvatskoga prijevoda Rumanca trojskoga $\left(\right.$ ff. $36 \mathrm{r}^{\mathrm{a}}-36 \mathrm{v}^{\mathrm{d}}$ ) i Cvijeta kreposti (ff. 50r ${ }^{\mathrm{a}}-54 \mathrm{r}^{\mathrm{b}}$ ) (usp. ŠTEFANIĆ 1970: 5; HERCIGONJA 1975: 379, 387). Taj djelomični zapis Rumanca trojskoga, pisan čakavskom stilizacijom hrvatskoga jezika, prvi je put objavljen još u 19. stoljeću u drugome dijelu gimnazijske čitanke Priméri starohèrvatskoga jezika iz glagolskih $i$ cirilskih književnih starinah koju je priredio Vatroslav Jagić (JAGIĆ 1866: 180-184; usp. ŠTEFANIĆ 1970: 7; BADURINA-STIPČEVIĆ 2011: 2-3), dok je Cvijet kreposti prvi priredio Rudolf Strohal, i to u zasebnoj knjizi Cvêt vsake mudrosti. Najstarije hrvatsko umjetno sačuvano književno djelo iz 14.

7 Budući da je u Jagićevoj čitanci Rumanac trojski iz Vinodolskoga zbornika preslovljen glagoljskim pismom, treba napomenuti da je u prvoj knjizi niza PSHK objavljena i latinična transkripcija te čakavske inačice zajedno s kraćim izvatkom iz cjelovito sačuvane čakavsko-kajkavske redakcije koja je zapisana na listovima ff. 323(331)r-332(340)r glagoljskoga Petrisova zbornika iz 1468. godine (Zagreb: NSK, sign. $R$ 4001) (ŠTEFANIĆ; GRABAR; NAZOR; PANTELIĆ 1969: 312-319; usp. HERCIGONJA 1975: 379). Inačicom iz Petrisova zbornika bavio se već Jagić koji je cijeli tekst transliterirao na ćirilicu i objavio ga u »Prilozima [...]« iz Kukuljevićeva Arkiva (JAGIĆ 1868: 121-135; usp. BADURINA-STIPČEVIĆ 2011: 6). Ta je inačica nedavno ponovno objavljena u nizu SHK u latiničkoj transkripciji koju je priredila Vesna BADURINA STIPČEVIĆ (2013: 261-275). Hrvatskoglagoljske su inačice Rumanca trojskoga zarana privukle pažnju povjesničara književnosti zato što je riječ o jednome od samo četiri romana u hrvatskim rukopisima iz srednjega vijeka (Rumanac trojski, Priča o premudrom Akiru) ili u njihovim ranonovovjekovnim prijepisima (Aleksandrida, Barlaam i Jozafat) (usp. ŠTEFANIĆ 1969.b: 46-48; BADURINA STIPČEVIĆ 2013: 22). Budući da povjesničari srednjovjekovne i ranonovovjekovne književnosti nerijetko favoriziraju svjetovne tekstove na štetu religioznih - vjerojatno zato što na književnu prošlost svjetonazorski bitno drugačijih razdoblja nesvjesno projiciraju svjetovne vrijednosti i moderni literarni ukus (usp. GAUNT 1995: 180) - može se naslutiti da je Rumancu trojskome status kanonskoga djela djelomično pribavila i činjenica da je riječ o jednome od rijetkih primjera svjetovnih književnih sastava u hrvatskim glagoljskim zbornicima (usp. HERCIGONJA 1975: 56, 377-384). Naposljetku, Rumancu važno mjesto u književnopovijesnim narativima o hrvatskoj književnosti zasigurno osigurava i činjenica da taj tekst - zajedno s Mukom sv. Andrije, Nikodemovim evanđeljem i Poslanicom o nedjelji (ŠTEFANIĆ 1969.b: 22) - potvrđuje posredničku ulogu hrvatske srednjovjekovne književnosti u prijenosu zapadnih obrada pojedinih književnih tema prema slavenskome Istoku (HERCIGONJA 1975: 55). Naime, dosadašnje usporedbe različitih slavenskih redakcija Rumanca upućuju na zaključak da je »vjerojatno krajem XIII. stoljeća u Hrvatskoj«»[p]rema neutvrđenom latinskom ili talijanskom predlošku nastao [...] i prvi slavenski prijevod ovoga romana, [...] a pretpostavlja se da su iz te matice potekle srpska, srednjobugarska i ruska redakcija (BADURINA STIPČEVIĆ 2013: 24; usp. JAGIĆ 1868: 136; KOMBOL 1961: 40-41; ŠTEFANIĆ 1969.b: 47; HERCIGONJA 1975: 378-379; FALIŠEVAC 1980: 66; BADURINA-STIPČEVIĆ 2011: 7). 
vijeka (STROHAL 1916: 12-43; usp. ŠTEFANIĆ 1970: 8). ${ }^{8}$ Osim o Rumancu i Cvijetu pisalo se i o nekoliko drugih tekstova iz Vinodolskoga zbornika, iako su pritom ipak najčešće bili korišteni tek kao poredbeni materijal u radovima koji su se primarno bavili drugim književnim izvorima, kao što je to npr. bio slučaj s Hercigonjinim člankom o duljoj redakciji Pavlove vizije iz Oxfordskoga zbornika (ff. 1r-8ra ) (Oxford: BL, sign. Ms. Can. lit. 414), koji se tek u završnome dijelu dotiče i njezine kraće redakcije koja je zapisana na ff. 34ra-35v Vinodolskoga zbornika (HERCIGONJA 1967: 251-253; usp. DÜRRIGL 2016: 16). ${ }^{9}$

8 Posrijedi je čakavski prijevod iznimno popularna talijanskoga srednjovjekovnoga poučnoga spisa Fiore di virtù, koji se sastoji od niza zasebnih poglavlja u kojima se naizmjenice raščlanjuju narav pojedinih kršćanskih vrlina i njima etički protivne neurednosti i grijesi (usp. ŠTEFANIĆ; GRABAR; NAZOR; PANTELIĆ 1969: 354-358; FALIŠEVAC 1980: 79-80; SAMBUNJAK 2001: 34-35). Priređujući izdanje Cvijeta kreposti iz Vinodolskoga zbornika Strohal je u lakune iz primarnoga predloška umetao odgovarajuće dijelove inačica koje su se sačuvale na ff. 5v-10r Ljubljanskoga zbornika iz 15. stoljeća (Ljubljana: NUK, sign. Slavische Sammlung, fut. 3, br. 368) i na ff. 67r-87r Tkonskoga zbornika s početka 16. stoljeća (Zagreb: Arhiv HAZU, sign. IV a 120) (STROHAL 1916: 4-5; usp. MILČETIĆ 1911: 231232; ŠTEFANIĆ 1970: 8, 32; HERCIGONJA 1975: 387; ZARADIJA KIŠ 2015.a: 423). Za zasebno izdanje inačice iz Tkonskoga zbornika vidi: SAMBUNJAK 2001: 117-143. Osim navedenih inačica kojima se bavio Strohal, u glagoljskom je korpusu poznato i više prijepisa pojedinih osnovnih i dopunskih poglavlja Cvijeta iz drugih glagoljskih zbornika, poput već spominjana Petrisova iz 1468. (ff. 27r-30v), Grškovićeva (Zagreb: Arhiv HAZU, sign. VII 32) iz druge polovice 16. stoljeća (ff. 55(60)v-59(64)v, 121(126)r-125(130)r) i dvaju Zbornika duhovnog štiva iz druge polovice 15. stoljeća: (A) Zagreb: Arhiv HAZU, sign. IV a 92, na ff. 128r-130v; (B) Zagreb: Arhiv HAZU, sign. IV a 48, na ff. 59(64)r-65(70)v (ŠTEFANIĆ 1970: 21, 26, 47, 49; HERCIGONJA 1975: 387; ZARADIJA KIŠ 2015.a; ZARADIJA KIŠ 2015.b: 128). Pored toga, na ff. 1r-25r dubrovačkoga ćiriličnoga zbornika Libro od mnozijeh razloga (Zagreb: Arhiv HAZU, sign. IV a 24) iz 1520. godine zapisana je štokavska redakcija Cvijeta koju je objavio Milan REŠETAR (1926: 1-36). Unatoč brojnosti publikacija koje se, barem usputno, dotiču hrvatskih inačica Cvijeta, sačuvani su tekstovi i dalje nedostatno jezično i komparatistički proučeni, pa stoga još uvijek postoje i određene nedoumice oko podrijetla njihovih izravnih predložaka (usp. ZARADIJA KIŠ 2015.b: 130). Na potrebu za jezikoslovnom analizom i sustavnijom usporedbom sačuvanih inačica upućuje neobrazložena tvrdnja Slavomira Sambunjaka da je potvrda iz Tkonskoga zbornika »prevedena s češkoga jezika«, a ne izravno s talijanskoga (SAMBUNJAK 2001: 34), što je najvjerojatnije rezultat Sambunjakova oslanjanja na neoprimjerenu i još uvijek neispitanu Štefanićevu tvrdnju da je u »crkvenim dramama i Cvêtu krêposti« iz Tkonskoga zbornika potvrđeno »nešto čak čeških« elemenata (ŠTEFANIĆ 1970: 30; usp. KRAMARIĆ 2015: 15).

9 Kraća hrvatskoglagoljska redakcija vjerojatno se temelji na nekome latinskome vrelu (ŠTEFANIĆ; GRABAR; NAZOR; PANTELIĆ 1969: 191; DÜRRIGL 2016: 16), dok je dulja priređena prema ranijemu crkvenoslavenskome prijevodu grčkoga teksta (HERCIGONJA 1967: 253; ŠTEFANIĆ; GRABAR; NAZOR; PANTELIĆ 1969: 191; DÜRRIGL 2016: 16). Zbog različita podrijetla dviju redakcija Pavlove vizije, Hercigonjino tekstološko zanimanje za dulju redakciju zapravo nije ni zahtijevalo da se podrobnije istraži kraća, koja je, osim u Vinodolskome zborniku, potvrđena i na ff. 24(29)v-28(33)r Grškovićeva zbornika (HERCI- 
Tekstovi iz Vinodolskoga zbornika bili su predmet različitih tipova književnopovijesnih istraživanja. Budući da potpuna bibliografija radova o tekstovima iz Vinodolskoga zbornika nadilazi tematski okvir ovoga rada, raznovrsnost primjenjivanih književnopovijesnih pristupa može se ilustrirati trima novijim člancima različita usmjerenja. Najdulju tradiciju imaju filološko-tekstološka istraživanja koja su usmjerena na utvrđivanje inojezičnih predložaka glagoljskih tekstova te na istraživanje odnosa među različitim njihovim inačicama. Takav tip istraživanja može se oprimjeriti nedavnom studijom Johannesa Reinharta, koji je pisao o podrijetlu hrvatskih crkvenoslavenskih inačica Čitanja o zlim ženama koje se $\mathrm{u}$ Vinodolskome zborniku sačuvalo na $\mathrm{ff} .1 \mathrm{r}^{\mathrm{b}}-2 \mathrm{r}^{\mathrm{b}}$ pod naslovom $k(a) p(i) t(u) l_{b}$ o zlê ženê (REINHART 2015: 354-355). ${ }^{10}$ Kao primjer genološko-poetološkoga istraživanja može se navesti rad Marije-Ane Dürrigl, koji je pisala o žanrovskome statusu i funkciji dvaju tematski bliskih egzempla koji su u Vinodolskome zborniku zapisani jedan za drugim, na f. 33r ${ }^{\mathrm{a}}$ (otb pakla $k(a) p(i) t(u l b)$ ) i na ff. $33 \mathrm{r}^{\mathrm{b}}-33 \mathrm{v}^{\mathrm{d}}$ (rič veliko čudna i želna v'sakomu razumêti [...]) (DÜRRIGL 2002; ŠTEFANIĆ 1970: 7), a bave se oprekama između onostranih paklenih kazni i rajskoga blaženstva (DÜRRIGL 2002: 124). ${ }^{11} \mathrm{Te}-$ matološkome obratu u proučavanju glagoljskih tekstova približava se rad u kojemu je Antonija Zaradija Kiš upozorila na tekstove s animalističkom građom u Vinodolskome zborniku koje nalazimo u Cvijetu kreposti na ff. 50ra-54r ${ }^{\mathrm{a}}$ zbornika te u zasebno zapisanome kapitulu o slavuju (slavich e(stb) malahta

GONJA 1967: 251; ŠTEFANIĆ 1970: 7, 46). Za izdanje redakcije iz Vinodolskoga zborni$k a$ vidi STROHAL 1917: 32-36. Dulju redakciju iz Oxfordskoga zbornika transliterirao je HERCIGONJA (1967: 222-242). Usp. DÜRRIGL 2013: 149.

${ }^{10}$ Nešto opširnija inačica toga »kapitula« zapisana je pod naslovom Čte(nie) ot zlihb žens na listovima ff. 68v-71v Berčićeva zbornika br. 5 (Sankt-Peterburg: RNB, sign. Bč. 5) koji je nastao krajem 15. stoljeća (REINHART 2015: 341, 351-354; usp. VIALOVA 2016: 202 208). Johannes Reinhart naglašava da hrvatske crkvenoslavenske inačice toga ženomrzačkoga teksta po sadržaju uvelike odgovaraju glavi jednoga grčkoga pastoralnoga priručnika koji se obično pripisuje Anastaziju Sinajskome (7. stoljeće) (Quaestiones et responsiones, CPG 7746), a njihovo krajnje slavensko ishodište pronalazi u bugarskome prijevodu toga Anastazijeva teksta na starocrkvenoslavenski jezik (REINHART 2015: 341-343, 350). Tvrdnju o bugarskome ishodištu hrvatskih crkvenoslavenskih inačica Reinhart potkrepljuje brojnim paralelama između hrvatske inačice iz Berčićeva zbornika br. 5 i inačice iz Svjatoslavova izbornika (Moskva: GIM, sign. 1043) iz 1073. godine (REINHART 2015: 343-345, 348-349), koji je zapravo pisan ruskom redakcijom crkvenoslavenskoga jezika, ali mu se sadržaj temelji na nesačuvanome bugarskome predlošku iz 10. stoljeća koji je u literaturi poznat kao Simeonov zbornik (REINHART 2015: 342-353; usp. DAMJANOVIĆ 2002: 139).

${ }^{11}$ Inačice tih dvaju tekstova sačuvale su se i u Petrisovu zborniku: prva je zapisana na f. 340(349)r, a druga na ff. 233(235)r-234(236)r (DÜRRIGL 2002: 122). Za izdanje obaju tekstova iz Vinodolskoga zbornika vidi: STROHAL 1917: 72-73. Za transliteraciju teksta na ff. 233r-234r Petrisova zbornika (Ot pripodobleniê b(o)žiê) vidi: DÜRRIGL 2002: 135-135. 
p’tica [...]) na f. 46r'a (ZARADIJA KIŠ 2015.a: 424-430). ${ }^{12}$ Ipak, unatoč tipološkoj raznovrsnosti dosadašnjih istraživanja, većina tekstova iz Vinodolskoga zbornika još uvijek nije pobudila veće zanimanje povjesničara hrvatske srednjovjekovne književnosti, a u toj je skupini dosad zaobilaženih tekstova i itinerar ot er(u)s(o)l(i)ma i groba božiê čt(enie) - $k(a) p(i) t(u l b)$ (CVinod, f. 15ra ŠTEFANIĆ 1970: 6).

Povjesničari hrvatske srednjovjekovne književnosti redovito nastoje upozoriti na sve poznate potvrde žanrova koji su skromno zastupljeni u sačuvanome korpusu zato što one znatno utječu na dojam o širini tadašnjega žanrovskoga sustava. Budući da je hrvatskoglagoljski itinerar iz Vinodolskoga zbornika jedina poznata inačica jeruzalemskoga itinerara u hrvatskim srednjovjekovnim rukopisima te uopće jedini poznati predstavnik svojega žanra u čitavoj hrvatskoj srednjovjekovnoj književnosti, nameće se pitanje što bi mogao biti uzrok previda te u dvostrukome smislu jedinstvene pojave u hrvatskoj srednjovjekovnoj kulturi. Izostanak zanimanja za hrvatskoglagoljski itinerar mogao bi biti povezan sa suhoparnošću opisa toga teksta u Štefanićevu katalogu Akademijinih rukopisa gdje se uz incipit i eksplicit spominje samo to da je posrijedi »[t]opografija života i smrti Kristove« (ŠTEFANIĆ 1970: 6). Takav opis pobuđuje sumnju da Štefanić zbog opsežnosti svojega kataloškoga projekta pri opisivanju Vinodolskoga zbornika nije stigao pomnije proučiti tekst o kojemu se ovdje raspravlja. Iako se izostanak nedvosmislene obavijesti da je riječ o itineraru može protumačiti i kao nehotična terminološka nepreciznost, teže je objasniti kako bi se nakon pažljiva i cjelovita čitanja toga teksta propustilo uočiti da se u njemu osim o Kristovu životu mjestimice govori i o lokalitetima na kojima se komemoriraju: (A) starozavjetne osobe i događaji: ot er(u)s(o)lima do vitleoma mile $\cdot g \cdot[=4]$ i e(stb) pol puti s(ve)ti iliê i mế cr(ê)kvu i vitlêomomb e(stb) grobs rahilin' (CVinod, f. 16ra ); naideš ednu vodu ku osladi pro(ro)kb elisei (f. 16v'); Prvo peĉ' dupla in 'di e pokopan' avram' $i$ isakb i êkov' $i$ s'svoimi ženami e sara reveka liê (f. $\left.16 \mathrm{v}^{\mathrm{d}}\right)$; (B) osobe i događaji iz kanonskih i apokrifnih novozavjetnih tekstova: oce mêsto v(b) komb v komb gos'poê s(ve)ta m(a) riê veliko lêtb s'ta po v'zneseniû · mêsto gdi obraše matiê za ap(usto)la · mêsto k'di pokopan' bê s 'tipan 'prvi m(u)č(eni)kb (f. 15rb); Naprid'naideš'mêsto gdi potekoše židove za apustoli gda nesihu têlo s(ve)te m(a)rie · i ê niki ot nih' nosila i tudi emu ruka us 'hanu i za m(o)l(it)vu

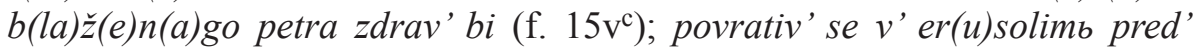
gradomb mêsto gdi pob 'en'bi stipanb (f. 15v $\mathrm{v}^{\mathrm{d}}$ ); i (C) djela kasnijih kršćanskih svetaca: I tu položi s(ve)ta elena k'rižb na mr(b)tv'ca i bi živ' (f. 16ra); [...] e(stb) grob's(ve)t(a)go eronima $\cdot i$ e(stb) peĉ gdi e stal' $i$ druga peĉb kdi bi

${ }^{12}$ Usp. VUČKOVIĆ 2017. 
poleženo veliko s(ve)tihb telesb (f. $1 \mathrm{r}^{\mathrm{b}}$ ). Ne dovodeći u pitanje neizmjerno visoku stručnu vrijednost Štefanićeva kataloga Akademijinih glagoljskih rukopisa (ŠTEFANIĆ 1969.a; ŠTEFANIĆ 1970), koji je zajedno s njegovim Glagoljskim rukopisima otoka Krka (ŠTEFANIĆ 1960) i Milčetićevom Hrvatskom glagolskom bibliografijom (MILČETIĆ 1911) postao jedan od temeljnih alata za istraživanje hrvatske glagoljske pismenosti, smatram da bi način na koji je u njemu opisan itinerar iz Vinodolskoga zbornika trebao potaknuti istraživače na sustavnije iščitavanje mnogobrojnih sažetije opisanih kapitula kod kojih opis ne omogućuje da se uvijek sa sigurnošću prepoznaju sadržaj pojedinih kapitula, njihova funkcija i njihove veze sa srodnim tekstovima u drugim glagoljskim zbornicima. ${ }^{13}$ Vjerojatno bi takve praznine bilo najprikladnije popunjavati digitalizacijom cjelovitih transliteracija ili transkripcija neliturgijskih zbornika mješovita sadržaja, ${ }^{14}$ jer bi cjelovitost ujedno omogućila da se pri interpretaciji tekstova redovitije uzima u obzir i kodikološki kontekst u kojemu se ti tekstovi pojavljuju. ${ }^{15}$

${ }^{13}$ Pronalaženje različitih zapisa istih kapitula otežava i to što je Štefanićev Indeks incipita nepotpun (usp. ŠTEFANIĆ 1970: 295-297). Međutim, poteškoće s pronalaženjem zapisa istih tekstova vjerojatno ne bi u potpunosti riješilo ni iscrpnije kazalo incipita, jer je poznato da su glagoljaši čak i kod sadržajno vjerna prenošenja istih neliturgijskih tekstova često mijenjali njihove naslove (DÜRRIGL 2006-2007: 132; DÜRRIGL 2007: 81).

${ }^{14}$ Istraživači hrvatskoga glagoljaštva još uvijek nisu započeli s priređivanjem digitaliziranih izdanja tematski i žanrovski heterogenih neliturgijskih glagoljskih zbornika. Osim toga, tiskanih je izdanja također malo, usprkos tomu što je nedostatak cjelovitih transliteracija neliturgijskih zbornika odavno prepoznat kao prepreka dinamičnijemu razvoju istraživanja jezika i književnosti hrvatskih glagoljaša (usp. HERCIGONJA 1975: 206-209; RJEČNIK 2000: II; SAMBUNJAK 2001: 5). Naime, među hrvatskoglagoljskim zbornicima dosad su cjelovito objavljeni samo (A) Berčićev zbornik br. 5 (Sankt Peterburg: RNB, sign. Bč. 5) iz druge polovica 15. stoljeća, koji je transliterirala Svetlana O. Vialova (VIALOVA 2016), (B) Tkonski zbornik (Zagreb: Arhiv HAZU, sign. IV a 120) iz prvih desetljeća 16. stoljeća, koji je transliterirao Slavomir Sambunjak (SAMBUNJAK 2001; usp. ŠTEFANIĆ 1970: 29-35) te (C) Fatevićev zbornik duhovnog štiva 1617., koji je transliterirala Grozdana Franov-Živković (BUNČUGA; FARIČIĆ; KERO 2016). Iako je Matija Valjavac već u 19. stoljeću cjelovito objavio Kolunićev zbornik iz 1486. godine (Zagreb: Arhiv HAZU, sign. III a 51) (VALJAVAC 1892; usp. ŠTEFANIĆ 1970: 15-18; RJEČNIK 2000: II), taj kodeks ima bitno drugačiju koncepciju od prethodno spomenutih neliturgijskih zbornika. Naime, u Kolunićevu zborniku zapisane su samo jedna odulja »zbirk[a] korizmenih propovijedi« i jedna »skolastičk[a] rasprav[a] o sedam smrtnih grijeha« pa bi se moglo reći da s neliturgijskim zbornicima koji sadržavaju širok raspon tematski i žanrovski heterogenih tekstova taj kodeks dijeli samo odrednicu »zbornik« u tradicionalnome filološkome imenu (ŠTEFANIĆ 1970: 18; usp. VALJAVAC 1892: V-X).

${ }^{15}$ U novijim medievističkim književnopovijesnim istraživanjima velika se pozornost pridaje kodikološkome kontekstu koji se smatra važnim čimbenikom u recepciji tekstova i mogućim pokazateljem njihova žanrovskoga identiteta (BUSBY; KLEINHENZ 2015: 217-218, 222 223). Međutim, Derek Pearsall filološku zaokupljenost kodikološkom cjelinom tumači kao 
Iako je itinerar iz Vinodolskoga zbornika u dosadašnjoj filološkoj literaturi prošao nezapaženo, taj se glagoljski tekst ipak spominje u jednome usputnome poglavlju Naši ljudi historiografske monografije Krešimira Kužića koja nosi naslov Hrvatska obala u putopisima njemačkih hodočasnika XIV. - XVIII. st. Opora - vinorodna - kršćanska (KUŽIĆ 2013: 168). Činjenica da je taj tekst prije zainteresirao povjesničara nego filologe možda i nije sasvim neobična ako imamo na umu da su u hrvatskoj znanstvenoj zajednici kroatistička književna medievistika i medievistička historiografija relativno tradicionalne i rijetko se upuštaju u teorijsku refleksiju o konstrukciji vlastitih postulata, metodoloških uzusa i disciplinarnih granica. ${ }^{16}$ Naime, $u$ znanosti o književnosti većina se srednjovjekovnih putopisa i itinerara dugo smatrala nedovoljno estetičnim i fikcionalnim tekstovima da bi im se uopće posvećivala veća istraživačka pažnja (usp. DUDA 1998: 7-8; BEEBE 2014: 3). ${ }^{17} \mathrm{~S}$ druge strane, povjesničari su takve tekstove pozitivistički proučavali i

posljedicu istraživačke frustracije zbog učestale odsutnosti autorske figure u srednjovjekovnoj književnosti na vernakularnim jezicima (PEARSALL 2005). Prema Pearsallu, navika nadomještanja odsutne autorske figure kodikološkim kontekstom može dovesti do toga da se oblikotvorno načelo počne pripisivati čak i rukopisima koji u stvari nisu imali planski ustrojen sadržaj (PEARSALL 2005). U kroatističkoj medievistici važnošću kodikološkoga konteksta bavila se Marija-Ana Dürrigl pri obradi dvaju sadržajno bliskih egzempla o paklenim mukama i rajskim blaženstvima koji se u Vinodolskome zborniku nalaze u susjednome položaju, dok ih u Petrisovu zborniku razdvaja veći broj listova (DÜRRIGL 2002: 121-122, 133; usp. DÜRRIGL 2007: 194). Iako nastoji pokazati da je kodikološki kontekst važan jer je mogao utjecati na čitateljsku percepciju različitih zapisa istoga teksta, Dürrigl je skeptična prema mogućnosti da se na temelju kriterija kodikološkoga konteksta provede historijski opravdano genološko razvrstavanje hrvatske srednjovjekovne književnosti (DÜRRIGL 2002: 133; DÜRRIGL 2007: 77). Ta se sumnjičavost temelji na dosadašnjim uvidima da su glagoljaši u obimnijim zbornicima tekstove ipak često zapisivali nasumično, tj. bez nastojanja da ih poredaju po nekomu unaprijed zacrtanu načelu (DÜRRIGL 2007: 77; usp. ŠTEFANIĆ 1960: 359).

${ }^{16}$ Za opis stanja u hrvatskoj historiografiji usp. BLAŽEVIĆ 2014: 25, 31. Kroatistička se književna medievistika nije bavila uzrocima vlastite tradicionalnosti. Jedan od načina na koji se očituje ta tradicionalnost upravo je potiskivanje metodološke refleksije, kojoj veću pažnja poklanja tek Dürrigl u brojnim metateorijskim komentarima (usp. DÜRRIGL 2007: 5-8, 80-81, 94-95, 99-101).

${ }^{17}$ Afirmaciji putopisa u znanosti o književnosti znatno je doprinijela pojava postmoderne teorijske paradigme koja je dekonstruirala dotad prešutno prihvaćane granice između fikcije i zbilje te literarnog i neliterarnog (usp. DUDA 1998: 9-10; BITI 2000: 397). Međutim, u književnoj medievistici zamah proučavanja putopisa započeo je tek s raznim oblicima kulturnoga obrata koji je književnopovijesna istraživanja čvršće povezao s historiografijom. Prije pojave postmodernoga »zanimanj[a] za rubne književne žanrove« (DUDA 1998: 9) i kulturnoga obrata veću pozornost znanosti o književnosti privukli su tek pojedini srednjovjekovni putopisi poput Mandevilleovih putovanja te Milijuna (tal. Il Millione) ili Knjige svjetskih čudesa (fr. Livre des merveilles du monde) Marka Pola, koje se lako moglo proglasiti ili 
sustavno izdavali već u 19. stoljeću, što se može oprimjeriti još uvijek često upotrebljavanim engleskim prijevodnim izdanjima srednjovjekovnih putopisa u Svetu zemlju koje je objavljivala udruga Palestine Pilgrims' Text Society (1884.-1896.) ili pak izdanjima i autorskim studijama njemačkih istraživača Titusa Toblera (1806.-1877.) i Reinholda Röhrichta (1842.-1905.) (usp. DORNINGER 2010: 2110). ${ }^{18}$

Iako Kužić uopće ne raščlanjuje sadržaj glagoljskoga itinerara iz Vinodolskoga zbornika, očigledno je da ga smatra dijelom kasnosrednjovjekovne hodočasničke kulture, jer ga povezuje s putovanjem u Jeruzalem koje je 1411. godine poduzeo Nikola IV. Frankapan (†1432.) (KUŽIĆ 2013:

potpuno (Mandevilleova putovanja) ili barem djelomično (Milijun) izmaštanim opisima na temelju toga što su zasićeni obavijestima koje su neuskladive s modernim prirodoznanstvenim, geografskim i antropološkim znanjima (usp. SCHNEIDER 2002: 166-169; DUDA 2012: 128-131; BEEBE 2014: 3). Međutim, to ne znači da su se ti tekstovi u srednjem vijeku smatrali nevjerodostojnima. Naime, mnogi čitatelji nisu dovodili u pitanje činjeničnost njihovih narativnih konstrukcija, o čemu jasno govori i povjerenje koje su u drugoj polovici 15. stoljeća Mandevilleovim putovanjima poklanjali Kristofor Kolumbo i Feliks Fabri (SCHNEIDER 2002: 166-168; DORNINGER 2010: 2105-2106). Štoviše, inkvizicijski spisi koji su proizvedeni krajem 16. stoljeća u sklopu procesā protiv polupismena, ali knjigama sklona furlanskoga mlinara Menocchija, koji je Mandevillea čitao u talijanskome prijevodu $\mathrm{Il} \mathrm{ca}$ vallier Zuanne da Mandavilla (GINZBURG 1980: 29), pokazuju da su se Mandevilleova putovanja u pučkoj recepciji ponekad čak i nakon velikih pomorskih otkrića s kraja 15 . i početka 16. stoljeća doživljavala kao izvor pouzdanih činjenica o svijetu (usp. GINZBURG 1980: 41-51, 88).

${ }^{18}$ Srednjovjekovni putopisi i itinerari ušli su u historiografski obzor već u okvirima predmodernoga antikvarstva i pozitivizma 19. stoljeća (usp. BEEBE 2014: 32-33). Za razliku od antikvarske publicistike i pozitivističkih istraživanja u kojima su se putopisi, vodiči i itinerari čitali kao vrela činjenica o opisivanim prostorima i njihovim stanovnicima, nakon jezičnoga i niza kulturnih obrata u suvremenoj historiografiji potvrde tih naizgled nefikcionalnih žanrova uglavnom su se počele tumačiti kao izvedbe kojima se svjesno ili nesvjesno proizvode ili aktualiziraju određeni diskursi o prostorima i njihovu stanovništvu (usp. SCHNEIDER 2002; BURKE 2010: 2-5; DUDA 2012: 34-35; BEEBE 2014: 31-37, 179). Ta promjena paradigme obilježila je historiografiju od sredine osamdesetih godina 20. stoljeća naovamo, kada je nastao gotovo nesaglediv korpus teorijski razrađenijih publikacija koje su posvećene srednjovjekovnim itinerarima i putopisima (usp. DORNINGER 2010: 2114-2115; BURKE 2010: 2). U vrijeme smjenjivanja tih paradigmi hrvatska historiografija te povijest umjetnosti i graditeljstva također se se počele intenzivnije baviti stranim srednjovjekovnim putopisima i itinerarima koji govore o putovanju hrvatskim povijesnim prostorom (usp. PIVČEVIĆ 1988; KRASIĆ 2001; KUŽIĆ 2013; BELAMARIĆ 2014: 172-175, 177-179, 182-183). Međutim, iako se u prilozima hrvatskih proučavatelja srednjovjekovnih putopisa $\mathrm{i}$ itinerara pozornost nerijetko poklanja i kulturnim temama poput hodočasničkih zapažanja o vizurama pojedinih naselja, njihovim svetačkim kultovima te načinu života i običajima lokalnoga stanovništva (usp. PIVČEVIĆ 1988: 189; KUŽIĆ 2013: 101-164), takvi se sadržaji i dalje pretežno promatraju iz pozitivističkoga gledišta, odnosno bez uočljivijih naznaka recepcije jezičnoga i kulturnih obrata. 
168). ${ }^{19}$ Međutim, veza između toga glagoljskoga itinerara i jeruzalemskoga hodočašća Nikole IV. Frankapana nije potvrđena nijednom izravnom obaviješću u vrelima, a upitno je i to može li se ta veza razložno uspostaviti na temelju ikakvih drugih obavijesti. Iako neke od sekundarnih bilješki iz Vinodolskoga zbornika pokazuju da se taj kodeks sredinom 15. stoljeća doista upotrebljavao među svećenicima iz najuže frankapanske društvene okoline $(\check{c} \cdot u \cdot m \cdot d[=1465]$ env(a)ra d(a)n $\check{2} \cdot[=7]$ kada ê mikula êketič to pisah v hridini va dvori kneza štefana i nega s(i)na brnardina ki imiše tada let $\cdot b i \cdot[=12]$ i bihi tada nega sluga [...]) (CVinod, f. 65v; usp. ŠTEFANIĆ 1970: 9-10; KRUHEK 2009: 191), u njemu nema nikakvih naznaka da je samo zapisivanje glagoljskoga itinerara na bilo koji način bilo povezano s čuvanjem pamćenja o spomenutome hodočašću Nikole IV. Frankapana. Kao prvo, glagoljski se itinerar po sadržaju ne može povezati s nekim određenim hodočasničkim činom, jer taj tekst - kao što će se pokazati u nastavku ovoga članka - ne prepričava hodočasničko iskustvo nekoga pojedinca ili skupine, nego funkcionira kao hodočasnički itinerar koji s implicitnim čitateljima pretežno uspostavlja odnos preko instance neimenovanoga naslovljenika kojemu se u drugome licu jednine upućuju tek uopćene obavijesti o razmještaju i redoslijedu obilaska hodočasničkih odredišta u Svetoj zemlji. Kao drugo, sumnju u povezanost glagoljskoga itinerara s frankapanskim obiteljskim pamćenjem donekle pojačava i njegov kodikološki smještaj, jer je taj tekst u Vinodolskome zborniku zapisan među raznim poučnim sastavima (usp. ŠTEFANIĆ 1970: 6). Unatoč teorijskim prijeporima oko toga koliko je kodikološki smještaj pouzdan ključ za prepoznavanje žanrovskoga identiteta i namjene srednjovjekovnih tekstova (usp. DÜRRIGL 2002: 133; PEARSALL 2005; DÜRRIGL 2007: 77), neizbježno se nameće pitanje nije li smještaj glagoljskoga itinerara među poučnom prozom ujedno i znak da je pisar taj tekst ponajprije smatrao još jednim poučnim kapitulom. ${ }^{20}$ U svakom slučaju, razvidno je da Kužićeva tvrdnja o okolnostima nastanka glagoljskoga itinerara nije mogla biti motivirana kodikološkim kontekstom. Stoga se može pretpostaviti da se tvrdnja o povezanosti glagoljskoga itine-

${ }^{19}$ Hodočašće Nikole IV. Frankapana poznato je iz jedne sekundarne bilješke na f. 185r prvoga sveska glagoljskoga Vatikanskoga brevijara Illirico 5 (Rim: BAV, sign. Borg. illir. 5): (1411.) [...] miseca aprila ide knez Mikula, naš gospodin plemeniti v' Jerusalim k božiem grobu $i$ pride domov iuliea, obhodiv dobro i časno (MILČETIĆ 1911: 513; usp. IBLER 2012: 251; KUŽIĆ 2013: 168; LADIĆ 2014: 105).

${ }^{20}$ Iako se itinerar iz Vinodolskoga zbornika na temelju dosadašnjih spoznaja ne može opravdano proglasiti frankapanskim memorijalnim tekstom, treba naglasiti da su neki srednjovjekovni opisi putovanja u Svetu zemlju doista bili primarno namijenjeni oblikovanju i čuvanju obiteljske predaje o vrijednim djelima predaka. Usp. WEBB 2002: 174-175; KUŽIĆ 2013: 28-30; DORNINGER 2014: 422. 
rara s hodočašćem iz 1411. temelji isključivo na povezivanju činjenice da je Nikola IV. Frankapan te godine hodočastio na Kristov grob u Jeruzalemu s pretpostavkom da Vinodolski zbornik potječe »iz početka XV. stoljeća « i da $» j$ e nastao na frankopanskom području « (KUŽIĆ 2013: 168). Međutim, takvo bi zaključivanje bilo višestruko problematično. Naime, kad bi se vrijeme putovanja Nikole IV. Frankapana doista okvirno podudaralo s pretpostavljenim vremenom i mjestom nastanka Vinodolskoga zbornika u kojemu je sačuvan glagoljski itinerar, to još uvijek ne bi značilo da među njima mora postojati i uzročno-posljedična veza. Osim toga, sumnju u uzročnost pojačava i postojanje brojnih podataka o drugim kasnosrednjovjekovnim hodočasnicima u Svetu zemlju koji su potjecali s hrvatskoga povijesnoga prostora, tim više što su među njima naročito brojni bili svećenici (KUŽIĆ 2013: 174; LADIĆ 2014: 107) među kojima je bilo i glagoljaša (RUNJE 2012: 76). ${ }^{21}$ Međutim, valja napomenuti da čak nije sigurno ni podudara li se vrijeme pisanja glagoljskoga itinerara s vremenom spomenutoga jeruzalemskoga hodočašća Nikole IV. Frankapana. Naime, kao što je pokazano u uvodnome dijelu ovoga članka, mnoge pojedinosti vezane uz pitanje mjesta i vremena nastanka Vinodolskoga zbornika još uvijek nisu do kraja razjašnjene. Osim toga, budući da neliturgijski zbornici mješovita sadržaja često obiluju kapitulima koji su samo prepisani iz znatno starijih rukopisnih knjiga, jasno je da se ni vrijeme postanka glagoljskoga itinerara ne mora nužno podudarati s vremenom njegova zapisivanja u Vinodolskome zborniku.

\section{HRVATSKOGLAGOLJSKI TEKSTOVI KAO ITEROLOŠKA GRAĐA}

Iako se glagoljski itinerar po Svetoj zemlji na temelju poznatih podataka ne može opravdano povezati s nekim pojedinačnim hodočasničkim činom, iz gledišta tematološki usmjerene znanosti o književnosti i historiografije koja je reagirala na kulturni obrat taj tekst ipak može biti zanimljivo vrelo za medievističku »iterologiju« (usp. DUDA 1998: 33), koja se bavi srednjovjekovnom »kulturom putovanja« (DUDA 2012: 21; usp. BURKE

${ }^{21}$ Većina radova o kasnosrednjovjekovnim hodočašćima $s$ hrvatskoga povijesnoga prostora temelji se na sadržaju privatnih oporuka koje su se sačuvale u formi zapisa u notarskim knjigama imbrevijatura iz različitih naselja na obali i otocima istočnoga Jadrana (KOLANOVIĆ 1982: 17-35; LADIĆ 1993: 23-24; LADIĆ 2005: 609; LADIĆ 2014: 95, 99). Podatci o hodočašćima u Svetu zemlju zasada su potvrđeni u porečkim (LADIĆ 2015: 27-28), rapskim (LADIĆ 2006; LADIĆ 2014: 106), zadarskim (LADIĆ 2014: 104-105) i šibenskim notarskim knjigama (KOLANOVIĆ 1982: 20-21; LADIĆ 2014: 106). Za podatke o hodočasnicima s hrvatskoga povijesnoga prostora koji su usput spomenuti u izvještajima stranih hodočasnika vidi: RUNJE 2012: 78; KUŽIĆ 2013: 171; LADIĆ 2014: 106-107. 
2010: 1-2), ${ }^{22}$ kao i za proučavanje konstrukcije prostora Svete zemlje u hrvatskoglagoljskoj književnosti i njegove funkcije u »kolektivnome pamćenju « (eng. collective memory prema fr. mémoire collective) hrvatskih glagoljaša (HALBWACHS 1992). ${ }^{23}$ Usporedi li se stanje istraživanja hrvatske srednjovjekovne književnosti s tendencijama u istraživanju njezina ranonovovjekovnoga korpusa, uočavaju se znatne razlike u njihovu stupnju zanimanja za iterološke teme. Te se razlike možda djelomično mogu objasniti činjenicom da se u hrvatskoj srednjovjekovnoj književnosti čak ni u mlađim prijepisima nije sačuvao nijedan pravi putopis, ${ }^{24}$ za razliku od ranonovovjekovnih stoljeća iz kojih se sačuvalo više predstavnika toga žanra. Iako najstariji sačuvani putopis na hrvatskome jeziku potječe tek iz sredine 18. stoljeća, kada je nastao rukopis Putovanje k Jeruzolimu god. 1752. Jakova Pletikose (Zagreb: NSK, sign. $R$ 4284) (usp. KRASIĆ 2001: 147; PAVLOVIĆ 2010), na drugim su jezicima hrvatski pisci već u 16. stoljeću napisali više putopisa među kojima dva opisuju upravo putovanje u Svetu zemlju (usp. KRASIĆ 2001: 146-147; PEDERIN 2007: 8-10; MILIČIĆ 2010). ${ }^{25}$ Naime, Bartol Đurđević je 1554.

${ }^{22}$ Zbog dinamične razmjene koncepata, istraživačkih pristupa i interpretacija među humanističkim i društvenim disciplinama koje proučavaju putovanja nastala je potreba za nazivom koji će se jezgrovito referirati na sveukupno znanstveno istraživanje putovanja iz kulturalnoga gledišta (usp. BURKE 2010: 1; DUDA 2012: 21). Među nazivima koji su stvoreni kako bi se udovoljilo toj potrebi najpoznatiji su engleski izraz travel studies i francuska riječ itérologie, koja potječe iz eseja Le voyage et l'écriture (1972.) u kojemu je Michel Butor zagovarao »utemeljenje [...] posebne znanosti o ljudskom premještanju, pomicanju ili kretanju « (DUDA 1998: 33; usp. BUTOR 1972: 7; BURKE 2010: 1; PAVLOVIĆ 2010: 145). Kad su i hrvatski povjesničari književnosti počeli temeljitije proučavati literarne obrade putovanjā, prilagodbom francuskoga pojma itérologie stvorena je i hrvatska terminološka istovrijednica iterologija (usp. DUDA 1998: 33; PAVLOVIĆ 2010: 145; DUDA 2012; GRMAČA 2015: 26).

${ }^{23}$ Usp. s temeljnim postavkama prostornoga obrata (eng. spatial turn) u znanostima koje proučavaju diskurzivnu proizvodnju različitih podjela geografskih prostora i njihova doživljavanja: BRKOVIĆ 2013; DUDA 2012: 14-15.

${ }^{24}$ Pripovijedanje u ranonovovjekovnim zapisima hrvatske inačice srednjovjekovnoga Istarskoga razvoda više se puta slikovito uspoređivalo s putopisnim diskursom (usp. NOVAK 1996: 163; HERCIGONJA 2006: 89-90). Međutim, čak i uz vrlo elastično shvaćanje putopisnoga žanra, valja imati na umu da je Istarski razvod ponajprije imao pravnu funkciju (BRATULIĆ 1978: 194, 197, 201), što znači da se eventualno može opisati kao primjer žanrovske hibridizacije u kojoj »putopisno izvješće ulazi kao bitni kompozicijski element u pravne spise« (HERCIGONJA 1975: 43; usp. FALIŠEVAC 1980: 87).

${ }^{25}$ Odnedavno se u mrežnim esejima i stručnoj literaturi pojavljuje podatak da je već 1480. godine hrvatski pisac Paolo da Stridone na talijanskome jeziku napisao ili objavio putopis Santo Viaggio in Terra Sancta (usp. VIDMAROVIĆ 2010; KONDRATENKO 2013: 92; LADIĆ 2014: 108). Međutim, pretpostavljam da je taj podatak posljedica (A) stapanja imena Santa Brasce s naslovom njegova putopisa Viaggio in Terrasanta iz 1480. godine i (B) nekritičkoga prijenosa pogrešnih interpretacija toga putopisa u kojemu Santo Brasca spominje da je za vrijeme putničke stanke na Korčuli bio i na obližnjoj Badiji gdje mu je franjevac Paolo da 
godine u Rimu na talijanskome jeziku objavio opis svojega zavjetnoga hodočašća u djelu Specchio della peregrinatione delli piu notabili luoghi della Terra santa di Promessione et delle processioni, et ceremonie che nella città di Hierusalem si sogliono celebrare, dok je Bonifacije Drkolica 1573. godine u Veneciji na latinskome jeziku objavio djelo Liber de Perenni cultu Terrae Sanctae et de fructosa eius peregrinatione (usp. KRASIĆ 2001: 146-147; MILIČIĆ 2010: 45; LADIĆ 2014: 108). Međutim, iako iterološka istraživanja obično »favorizira[ju] putopis kao najzahvalniji žanr« (DUDA 2012: 41), trebamo uzeti u obzir i to da je u književnosti »putovanje [...] među najfrekventnijim temama« (DUDA 1998: 32; usp. DUDA 1998: 44-47), što znači da se pronalaženje iterološki relevantna materijala može očekivati i u drugim knji-

Stridone uz neke vlastoručne tekstove poklonio i kartografski prikaz Svete zemlje: »Costui essendo $[\ldots]$ stato più tempo in Ierusalem, et exhortandone al viagio, ne mostroe designato in una carta el paese di Terra Sancta et molte altre gentilleze di sua mano [...] « (GRACIOTTI 2014: 336; usp. RUNJE 1997: 507). Iako se ne može isključiti mogućnost da se među fra Paolovim vlastoručnim zapisima doista nalazio i neki itinerar ili putopis, u pripovijedanju Santa Brasce nema određenijih obavijesti o sadržaju ili naslovu toga rukopisa. Zoran Ladić ne navodi neki drugi povijesni izvor ili bibliografske detalje o tobožnjem fra Paolovu putopisu koji bi nosio naslov Santo Viaggio in Terra Sancta. Međutim, činjenica da se njegov popis ranih hrvatskih putopisa u Svetu zemlju čak i kod toga u izvorima nigdje potvrđena detalja podudara s onima koje donose Đuro Vidmarović i Kateryna Kondratenko sugerira da bi ta tri popisa hrvatskih putopisa u Svetu zemlju mogla biti po postanku povezana (LADIĆ 2014: 108; usp. VIDMAROVIĆ 2010; KONDRATENKO 2013: 92). Kondratenko je pogrešan podatak najvjerojatnije preuzela izravno iz Vidmarovićeva eseja koji se spominje i u popisu literature koju je upotrebljavala pri pisanju članka (usp. KONDRATENKO 2013: 96). Nadalje, treba napomenuti da Vidmarovićev popis hrvatskih putopisa u Svetu zemlju uvelike podsjeća i na jedan stariji popis Adalberta Rebića (usp. VIDMAROVIĆ 2010; REBIĆ 1984: 555, 559560). Međutim, Rebićev se popis razlikuje od prethodno spomenutih upravo u dijelu koji se odnosi na Paola da Stridonea. Naime, Rebić zapravo tvrdi da je Paolo da Stridone bio čitatelj teksta Santo Viaggio in Terra Santa, a ne njegov autor: »Neki su franjevci opisali hodočašćenje u Svetu zemlju ili Svetu Zemlju naprosto. Tako fra Paolo da Stridone citira 1480. knjigu Santo Viaggio in Terra Santa (Milano, 1480, fototiskom ponovljeno 1966.)« (REBIĆ 1984: 555). Bibliografski podatci iz toga citata očigledno su pogrešni. Naime, godine u Rebićevim zagradama odgovaraju podatcima o vremenu izdanja putopisa Santa Brasce koji nosi naslov »Viaggio in Terrasanta di Santo Brasca, 1480 con l'Itinerario di Gabriele Capodilista, 1458, a cura di Anna Laura Momigliano Lepschy, Milano, Longanesi, 1966« (GRACIOTTI 2014: 333), a ne naslov Santo Viaggio in Terra Santa (REBIĆ 1984: 555, 559). Teško je pritom ne zamijetiti sličnost između »konstruiranoga« naslova fra Paolove lektire koja se spominje u Rebićevu tekstu (REBIĆ 1984: 555) i naslova Santo Viaggio in Terra Sancta koji fra Paolu pripisuju mlađi popisi hrvatskih hodočasničkih putopisa o Svetoj zemlji (VIDMAROVIĆ 2010; KONDRATENKO 2013: 92; LADIĆ 2014: 108). Iako se na temelju sličnosti među dvama nespretno »izmišljenim « naslovima može relativno uvjerljivo uspostaviti veza između Rebićeva popisa i spomenutih mlađih popisā hrvatskih hodočasničkih putopisa, ostaje nejasno jesu li onda ti mlađi popisi potekli izravno iz Rebićeva ili svi spomenuti popisi crpu iz nekoga zajedničkoga prototipa. 
ževnim žanrovima (usp. DORNINGER 2010: 2102-2103). Ipak, kada je riječ o istraživanjima književnih putovanja izvan putopisnoga žanra, treba naglasiti da su i ona učestalija među znanstvenicima koji se primarno bave hrvatskom književnošću ranoga novoga vijeka (usp. PLEJIĆ POJE 2010; TATARIN 2010; GRMAČA 2015) nego u hrvatskoj književnoj medievistici gdje se zanimanje za književno putovanje uglavnom očitovalo u istraživanju hrvatskih srednjovjekovnih vizija (DÜRRIGL 2006; GRMAČA 2015: 79-110), iako ni u drugim srednjovjekovnim pripovjednim i poučnim žanrovima ne nedostaje tekstova koje bi vrijedilo proučiti s iterološkoga gledišta (usp. MILIČIĆ 2010: 44-45).

Budući da je ovaj članak ponajprije posvećen itineraru koji je povezan $\mathrm{s}$ hodočašćima u Svetu zemlju, kao ilustrativan primjer pripovjednoga hrvatskoglagoljskoga srednjovjekovnoga teksta koji nije izravno povezan s putničkom praksom, a ipak donosi iterološki zanimljiv materijal o hodočašćima može se spomenuti jedna priča o Bogorodičinu čudu koja je zapisana na ff. $100 \mathrm{v}-102 \mathrm{r}$ Ivančićeva zbornika koji je nastajao kroz više godina krajem 14. i početkom 15. stoljeća (Zagreb: Arhiv Provincije franjevaca trećoredaca glagoljaša) (PETROVIĆ 1972: 152-153; usp. MILČETIĆ 1911: 258). Riječ je o mirakulu koji se sadržajno oslanja na znatno opširnije legendarne priče o Mariji Egipatskoj, ali se zadržava samo na temi jeruzalemskoga moralnoga obraćenja te svetice (PETROVIĆ 1972: 186-187). U tekstu se pripovijeda kako se negdje u Egiptu grešnica Marija priključila većoj skupini hodočasnika koji su putovali u Jeruzalem s namjerom da se poklone pred Kristovim križem i tako dobiju oproštenje grijeha, ali naposljetku zbog njezine neokajane bludne prošlosti Božja volja Mariji Egipatskoj onemogućuje ulazak u jeruzalemsko svetište sve dok joj ta milost nije udijeljena nakon duboka kajanja, rasplakane molitve i Bogorodičina zagovora (usp. PETROVIĆ 1972: 152-153, 184-187; TATARIN 2003: 233-244). Iako se u mirakulu hodočašće spominje kao kontekst dolaska Marije Egipatske u Jeruzalem, njezini motivi za odlazak na hodočašće nisu izravno predstavljeni. Naime, pripovijedanje u tome mirakulu naglašava samo to da je Marija Egipatska na put krenula po v(o)li b(o)žii (PETROVIĆ 1972: 152), što se odnosi na providnost koja je postupno pripremala njezinu "privatnu ispovijed kroz koju postaje vidljiv unutarnji lom u duši« dotadašnje grešnice koja potom svjetovne senzualne užitke zamjenjuje isposništvom (TATARIN 2003: 236-237). S druge strane, takvomu neutralnomu vrednovanju hodočašća iz glagoljskoga mirakula o obraćenju Marije Egipatske može se suprotstaviti negativnije sižejno vrednovanje hodočasničkoga morala u jednome dijelu europske legendarne tradicije o toj svetici u kojemu se kao osnovni motiv koji je buduću preobraćenicu potaknuo da se priključi hodočasnicima navodi njezino prepoznavanje takva putovanja kao dobre prilike za promi- 
skuitetne užitke (usp. TATARIN 2003: 126-132). Vrednovanje kakvo nam posreduje ta latinska legendarna tradicija nije sasvim atipično. Naime, unatoč njihovoj popularnosti među srednjovjekovnim svećenstvom i pastvom, hodočašća su nerijetko bila žestoko kritizirana kao oblik nerazborite rasipnosti te naivnoga shvaćanja religioznosti ili kao izlika za svjetovne pustolovine pastve i prigoda za namicanje materijalnih dobara Crkvi (usp. WEBB 1999: 235-254; WEBB 2002: 71-77; LADIĆ 2014: 96-98). Međutim, iterološka zanimljivost glagoljskoga mirakula o obraćenju Marije Egipatske iz Ivančićeva zbornika leži upravo u odsutnosti negativna vrednovanja hodočasničkoga morala koje je potvrđeno $u$ brojnim hagiografskim tekstovima o toj svetici (usp. TATARIN 2003: 234, 242), što ujedno pokazuje da srednjovjekovni tekstovi nisu nužno promicali svjetonazorski ujednačena vrednovanja čak ni onda kada su obrađivali iste epizode iz života nekoga svetca. ${ }^{26}$ Odsutnost negativnoga vrednovanja hodočašća u spomenutome mirakulu iz Ivančićeva zbornika dopušta da se postavi istraživačko pitanje jesu li hrvatski srednjovjekovni glagoljaši u svojim tekstovima bili dosljedno skloni pozitivnome vrednovanju hodočašća ili su uglavnom posuđivali vrednovanja potvrđena u predlošcima kojima su se služili.

\section{SADRŽAJ ITINERARA IZ VINODOLSKOGA ZBORNIKA}

\subsection{Prikaz sadržaja}

Itinerar ot er(u)s(o)l(i)ma i groba b(o)žiê čtt(enie) $\cdot k(a) p(i) t(u l b)$ (CVinod, f. $\left.15 r^{a}\right)$ implicitnoga korisnika vodi po mjestima koja su se u srednjovjekovnome stupnju razvoja kršćanskoga »kolektivnoga pamćenja« smatrala poprištima najvažnijih zbivanja u povijesti Spasenja (HALBWACHS 1992). Početak itinerara postavlja stvarnoga ili virtualnoga hodočasnika u Crkvu Svetoga groba, što je sigurno imalo simboličku težinu koja se očituje i u činjenici da se taj lokalitet često spominjao kao sinegdoha za hodočašće u Svetu zemlju (DORNINGER 2014: 423; usp. LADIĆ 2014: 95, 105-106, 108), a u srednjem se vijeku nerijetko smatrao i »središtem zemlje« (DORNINGER 2014: 423-424; usp. WRIGHT 1925: 259-260; MORRIS 2005: XIX-Xx; KUŽIĆ 2013: 22). Kazivač naglašava da u Crkvi Svetoga groba nakon razgledavanja mjesta raspeća i samoga groba treba otići do Golgote, ${ }^{27}$ koja se pamti

${ }^{26}$ Usp. sa slično koncipiranim argumentom o varijacijama među starohrvatskim pasionskim prikazanjima: VUČKOVIĆ 2012: 144.

${ }^{27}$ Toponimi Golgota i Kalvarija u glagoljskim se prijevodima novozavjetnih čitanja uglavnom upotrebljavaju kao sinonimi (BADURINA STIPČEVIĆ 2014: 14-15). Međutim, u itineraru iz Vinodolskoga zbornika među njima se ipak uspostavlja značenjska opreka koja je potvr- 
kao mjesto pronalaska Adamove lubanje, a potom i do niza kapela u kojima se komemoriraju legenda o Jeleninu pronalasku Križnoga Drveta (Inventio crucis), Kristovo utamničenje, Josipovo i Nikodemovo žalovanje nad mrtvim Kristovim tijelom, Marijino supatništvo u vrijeme Kristove muke te Magdalenin susret s uskrslim Kristom (f. $15 \mathrm{r}^{\mathrm{rb}}$ ). Nakon posjeta Crkvi Svetoga groba itinerar usmjerava naslovljenika prema brdu Sion i upozorava ga da se na tome pravcu nalaze mjesto mučeništva Jakova Starijega Zebedejeva, Kajfina kuća koja je pretvorena u Crkvu sv. Spasitelja, kuća u kojoj je Marija živjela nakon Kristova uzašašća, Davidov grob, dvorana Posljednje večere, različita mjesta na kojima su se okupljali apostoli i crkva u kojoj se komemorira Petrovo kajanje zbog zatajenja Krista (f. $15 \mathrm{r}^{\mathrm{b}}-15 \mathrm{v}^{\mathrm{c}}$ ). Put se nastavlja uz ribnjak Siloe, koji se pamti kao mjesto na kojemu je Krist nekome prosjaku čudesno izliječio sljepoću (f. $15 \mathrm{v}^{\mathrm{c}}$ ). Potom prolazi kroz Dolinu Jošafat i Cedronsku dolinu kojom se dolazi do mjesta Kristove agonije u Getsemanskome vrtu i Bogorodičina groba (f. $15 \mathrm{v}^{\text {cd }}$ ). Nakon toga kazivač upućuje naslovljenika da na Maslinskoj gori posjeti mjesto Kristova uzašašća te mjesta na kojima su nastali Očenaš i Vjerovanje (f. $15 \mathrm{v}^{\mathrm{d}}$ ). Na povratku u Jeruzalem predloženi put vodi do mjesta smaknuća Stjepana Prvomučenika, a po ulasku u grad do crkve $\mathrm{u}$ kojoj se komemorira Marijino rođenje (ff. $15 \mathrm{v}^{\mathrm{d}}-16 \mathrm{r}^{\mathrm{a}}$ ). Prolazi se potom uz Pilatovu i Herodovu kuću i konačno se dolazi na put koji je poznat kao Via dolorosa (f. 16ra ${ }^{\mathrm{a}}$. Zatim se planira hodočašće u Betlehem s postajama u samostanu sv. Ilije te kod Rahelina groba (f. $\left.16 \mathrm{r}^{\mathrm{a}}\right)$. Kao glavna mikroodredišta u samome Betlehemu spominju se mjesto Kristova rođenja i Jeronimova špilja $\left(f .16 r^{\mathrm{ab}}\right)$. Nakon posjeta Betlehemu slijedi put u Betaniju, gdje je Krist vratio život preminulome Lazaru (f. $16 \mathrm{r}^{\mathrm{b}}$ ). Hodočasnik se potom vodi do Jordana, Gilgala s 12 jordanskih stijena koje simboliziraju izraelska plemena, mjesta Kristove kušnje te mjesta na kojemu je prorok Elizej pročistio nezdravu jeri-

đena i u nekim stranim vrelima (usp. MORRIS 2005: 25), iako raskorak između glagoljaških i modernih interpunkcijskih navika možda donekle otežava njezino razabiranje: $\operatorname{Vcr}(\hat{e}) k v i$ s(veta) go groba pitaite sihb mêst'vr'hb kalbvarie · Iv'kom vrhu bê raspetb is $(u) h(r b s t) b \cdot i$ vb grobs v'ki bi vložen gol'gota · V komb mêsti bi našasta gl (a)va adamova (CVinod, f. 15ra). Naime, toponim Kalvarija odnosi se ili (A) na mikrolokalitet raspeća ili (B) na zemljište na kojemu je sagrađena Crkva Svetoga groba (usp. MORRIS 2005: 25, 27-28). S druge strane, naziv Golgota vjerojatno se odnosi samo na stijenu u koju je bio uglavljen Kristov križ, ako ne i isključivo na kriptu u unutrašnjosti te stijene gdje je prema jednoj od predaja bila pronađena Adamova lubanja (usp. MORRIS 2005: 25, 27-28). Predaja o Adamovu ukopu pod mjestom raspeća bila je vrlo raširena u kršćanstvu, iako valja napomenuti da je istovremeno postojala i predaja prema kojoj je Adam bio pokopan u Hebronu (usp. MORRIS 2005: 28; HILHORST 2007: 133-136). Hebronska je predaja bila osobito popularna među Židovima, ali se mjestimice susreće i u tekstovima kršćanskih srednjovjekovnih teologa, što se uglavnom može povezati s utjecajem Jeronimovih rasprava u kojima se gorljivo branila njezina vjerodostojnost (HILHORST 2007: 133-134; usp. MORRIS 2005: 28). 
honsku vodu (f. $16 \mathrm{r}^{\mathrm{b}}-16 \mathrm{v}^{\mathrm{c}}$ ). Nakon toga slijede put prema Jakovljevu zdencu u Siharu, gdje se Krist susreo sa Samarijankom, i posjet Sebasti, gdje se štuje Ivan Krstitelj (f. $\left.16 v^{c}\right)$. Sljedeći su hodočasnički ciljevi Crkva rođenja Ivana Krstitelja u blizini Jeruzalema, mjesto gdje je posječeno križno drvo i Lavlja špilja s brojnim relikvijama (f. $16 \mathrm{v}^{\mathrm{cd}}$ ). Itinerar se zaključuje odlaskom u hebronski kraj, gdje se nalaze grob patrijarhā te neki lokaliteti koji se vežu uz stvaranje Adama i njegovo oplakivanje Abelove smrti (f. $16 \mathrm{v}^{\mathrm{cd}}$ ).

\subsection{Redoslijed izlaganja}

Forma tractatus glagoljskoga itinerara progresivno je linearna utoliko što redoslijed iznošenja obavijesti dosljedno prati zamišljeni redoslijed obilaska postaja na hodočašću koje se planira za implicitnoga korisnika toga teksta. Međutim, to ne znači da je i samo hodočašće bilo progresivno linearno strukturirano u odnosu prema biblijskoj i ranokršćanskoj povijesti Spasenja koju je to putovanje trebalo prostorno komemorirati (usp. CARRUTHERS 1998: 43). Ovdje je ponajprije zanimljivo obratiti pozornost na odnos između početne i završne postaje hodočašća među kojima se uspostavlja efektan kontrapunkt koji naglašava Kristovu poveznicu s Adamovim čovještvom, ali i oprečnost $u$ naravi i učinku Kristova i Adamova djelovanja. Naime, kao što se može vidjeti iz gore prepričana sadržaja, za početnu točku hodočasničkoga puta odabrana je crkva u kojoj se komemorira mjesto Kristova raspeća i njegov ispražnjeni grob, koji simbolizira ispunjenje Božjega plana i konačnu pobjedu nad smrću, dok je za završnu točku u obilasku svetih mjesta odabran hebronski kraj u kojemu se komemorira Božji čin stvaranja Adama po čijemu je grijehu čovjek i postao smrtan. Može se pretpostaviti da su ciljani korisnici glagoljskoga itinerara raspolagali s dovoljno znanja da uoče taj kontrapunkt. Naime, posrijedi su temeljne i široko rasprostranjene kršćanske teološke ideje koje su bile jasno artikulirane već u Pavlovoj Poslanici Rimljanima u kojoj se razrađuje pitanje odnosa Adama i Krista: »Zbog toga, kao što po jednom Čovjeku uđe u svijet grijeh i po grijehu smrt, i time što svi sagriješiše, na sve ljude prijeđe smrt. Doista, do Zakona bilo je grijeha u svijetu, ali se grijeh ne ubraja kad nema zakona. Da, ali smrt je od Adama do Mojsija doista kraljevala i nad onima koji ne sagriješiše prekršajem sličnim kao Adam, koji je pralik Onoga koji ima doći. Ali s darom nije kao s grijehom. Jer ako su grijehom jednoga mnogi umrli, mnogo se obilatije na sve razlila milost Božja, milost darovana u jednom čovjeku, Isusu Kristu « (Rim 5,12-15) (JERUZALEMSKA BIBLIJA 2001: 1609-1610). Budući da prikaz teologijske recepcije ovih misli iz Poslanice Rimljanima i njima tematski bliskih redaka iz Prve poslanice Korinćanima (1Kor 15,20-23) uvelike nadilazi mogućnosti ovoga rada (usp. 
VUGDELIJA 1993: 254-255), raširenost takvih teoloških ideja može se pokazati i na primjeru njihova odjeka u popularnim srednjovjekovnim narativnim i refleksivnim tekstovima. Naime, upravo posežući za primjerima iz popularne književnosti možemo najjasnije razabrati da su se spomenute ideje o odnosu Krista i Adama smatrale prevažnima da bi ostale samo preokupacijom relativno malobrojnih visoko naobraženih egzegeta. Među popularnim srednjovjekovnim književnim tekstovima koji su se temeljili na nadgradnji takvih pavlovskih ideja osobito vrijedi upozoriti na srednjovjekovnu Legendu o Križnom drvetu $» k$ koje je izraslo iz grančice što ju je Adamov sin Set zasadio na očevu grobu« da bi ga Židovi nakon Kristova uhićenja iskoristili kao materijal za izradu njegova otkupiteljskoga križa (DÜRRIGL 2006: 62) ${ }^{28}$ Nadalje, refleksivni tekstovi u kojima se Kristova muka izravno povezuje s različitim aspektima prvoga grijeha potvrđeni su i u Vinodolskome zborniku, i to upravo unutar iste kodikološke jedinice u kojoj je zapisan itinerar po Svetoj zemlji. Ta se tema naročito izravno naglašava u dvostruko zapisanu kapitulu koji se nalazi na ff. $10 \mathrm{r}^{\mathrm{b}}-11 \mathrm{v}^{\mathrm{d}}$ pod naslovom Ot muki g(ospo)dne $k(a) p(i) t(u l b)\left(\mathrm{f} .10 \mathrm{r}^{\mathrm{b}}\right)$, a potom i na f. $32 \mathrm{r}^{\mathrm{b}}-32 \mathrm{v}^{\mathrm{d}}$ pod naslovom Ot muki h(rbsto)vi k(a)p(i)t(ulb) (f. 32r $\mathrm{r}^{\mathrm{b}}$ ) (usp. ŠTEFANIĆ 1970: 7). Naime, u jednome dijelu spomenutoga kapitula opisuje se kako je Kristov otkupiteljski čin zahtijevao mučenje svih onih osjetila kojima je bio počinjen i Adamov prvi grijeh (ŠTEFANIĆ 1970: 7), što se može oprimjeriti komentarima o vidu i sluhu iz zapisa na f. $32 \mathrm{r}^{\mathrm{b}}-32 \mathrm{v}$ d: $i$ skrozê to da

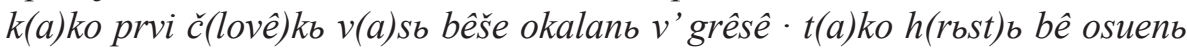
po vsemb $t(\hat{e}) l \hat{e} \cdot I k(a) k o$ pr(b)vi č (lovê) kb adamb s'grêši v pogledan' $i \cdot t(a) k o$ $h(r b s t)_{b}$ bê osuenb $v$ pogledan'i začb zakriše lice ego $\cdot i k(a) k o$ prvi č (lovê) $k b$ s'gr(ê)ši v'slišan 'i to e (stb) slišeci gl (a)sb kač' $i \cdot$ da bi jêllb ot êb'lka starago · i t(a)ko h(rbst)b bê osujenb v slišan'i to e(stb) slišeĉi k'da mimohodece psovahu $i\left(\mathrm{f} .32 \mathrm{v}^{\mathrm{c}}\right)$. Naposljetku, pretpostavku o prepoznatljivosti kontrapunkta između polazišne i završne točke itinerara može opravdati i njegova potvrđenost u programu same polazišne postaje, jer se u Crkvi Svetoga groba, kao što je već spomenuto, nalazi i Adamova kapela koja je smještena upravo u kripti pod mjestom koje tradicija povezuje s Kristovim raspećem (usp. MORRIS 2005: 25, 27-28; BAERT 2004: 170). ${ }^{29}$

${ }^{28} \mathrm{Za}$ potvrde Legende o Križnom drvetu u hrvatskoj književnosti vidi: JAGIĆ 1868: 92-97; ŠTEFANIĆ; GRABAR; NAZOR; PANTELIĆ 1969: 159; MIHALJEVIĆ; VINCE 2012: 128-131; DÜRRIGL 2013: 82-83. O popularnosti te priče svjedoči i činjenica da su neki njezini elementi ušli u narativnu potku pojedinih redakcija apokrifa Život Adama i Eve (TURKALJ 2006-2007: 584). Za prikaz nastanka Legende o Križnom drvetu i više podataka o njezinoj transmisiji u kršćanskoj ekumeni vidi: BAERT 2004: 289-349; FALLON 2009: 3-37.

${ }^{29}$ Vidi komentar Mary Carruthers koja se u knjizi The Craft of Thought osvrće na ranokršćansku sklonost prema »retoričkome« ili prefiguracijskome supostavljanju lokaliteta na kojima 
Prihvatimo li hipotezu da se pri planiranju hodočašća koje je opisano u glagoljskome itineraru nastojalo naglasiti kontrapunkt između polazišne i završne točke putovanja, trebalo bi se osvrnuti i na redoslijed njihova pojavljivanja. Naime, ovdje se nameće pitanje zašto se odabranim redoslijedom hodočasničkih odredišta povijest Spasenja komemorirala obrnutim redoslijedom - od Kristove žrtve do grijeha zbog kojega je ona bila potrebna. Odstupanje strukture hodočašća od kronologije događaja koji su se tim hodočašćem komemorirali isprva je moglo biti povezano s namjerom da se povijesni poredak stvari zamijeni važnosnim. Međutim, ustaljivanju toga redoslijeda mogla je doprinijeti i činjenica da se za vrijeme mamelučke kontrole nad Svetom zemljom slobodno kretanje katoličkih hodočasnika na tome prostoru smatralo ponešto rizičnim, što je hodočasnike poticalo da se odmah po dolasku u Svetu zemlju oslone na kakvu-takvu hodočasničku infrastrukturu koja se razvila u Jeruzalemu u drugoj polovici 14. stoljeća. Naime, tada su putnici iz Europe u Jeruzalemu mogli očekivati nešto lakše snalaženje u nepoznatome kulturnome okruženju zahvaljujući mogućnosti da se prepuste organizacijskim sposobnostima i praktičnim iskustvima malobrojnih franjevaca iz samostana na jeruzalemskoj gori Sion (usp. RUDY 2000: 496; MORRIS 2005: 301, 312; CAMPOPIANO 2012: 76-77; KUŽIĆ 2013: 21-23, 184; LADIĆ 2015: 29). ${ }^{30}$ Međutim, vjerojatno ne treba posebno isticati da je već i sama pojava

su se obilježavali »ključni događaji Staroga i Novoga zavjeta«: CARRUTHERS 1998: 43. Usp. HALBWACHS 1992: 213-215, 219.

${ }^{30}$ Kada je mamelučka vojska zauzećem Akre 1291. godine dokrajčila križarsko Jeruzalemsko Kraljevstvo, započelo je višedesetljetno razdoblje gotovo potpuna odumiranja katoličkih hodočašća po Svetoj zemlji (MORRIS 2005: 295, 301-302; usp. RICHARD 1996: 683), iako su se ona znatno prorijedila već nakon što je 1187. godine Saladin osvojio Jeruzalem (WEBB 1999: 86; MORRIS 2005: 273). Budući da je zamiranje katoličkih hodočašća u Svetu zemlju bilo nametnuto vanjskim okolnostima, istovremeno je došlo do osnaživanja predodžbe o njihovoj važnosti i potrebi da se katolicima što prije omogući neometan pristup Crkvi Svetoga groba (usp. MORRIS 2005: 295-301). Stoga se u katoličkim zemljama počelo intenzivno zagovarati i pokretanje novoga vala križarskih misija (LADIĆ 1999: 49-51; MORRIS 2005: 297-298). Iako zbog političkih konstelacija u samoj Europi i na željenoj fronti to propagandno djelovanje u konačnici nije potaknulo nove oružane misije, poduzetnost $u$ širenju prokrižarske ideologije zorno se ogleda u činjenici da su brojni oporučitelji na kraju 13. i početku 14. stoljeća bili spremni na izdašna novčana izdvajanja u korist novih križarskih vojnih pohoda (usp. LADIĆ 1999: 51-55; MORRIS 2005: 297-298; LADIĆ 2014: 99-102). Željama kasnosrednjovjekovnih katolika da im se omogući pristup Crkvi Svetoga groba naposljetku je udovoljila uspostava diplomatskih odnosa s Mamelučkim Sultanatom od kojega su franjevci 1333. godine ishodili dopuštenje da se nastane na jeruzalemskoj gori Sion uz pravo na uporabu niza memorijalno-sakralnih građevina i prostora među kojima je bila i Crkva Svetoga groba (WEBB 1999: 87; MORRIS 2005: 302-303; CAMPOPIANO 2012: 76). Osim na tada ispregovaranim pravima, organizacijska podrška koju su hodočasnici dobivali od sionskih franjevaca temeljila se i na međukulturnim kompetencijama članova te redov- 
te jeruzalemske infrastrukture bila povezana s hijerarhizacijom lokaliteta $\mathrm{u}$ katoličkom »kolektivnom pamćenju«. Naime, diplomatska nastojanja napuljskoga kralja Roberta Anžuvinca i prosjačkih redova da omoguće uspostavu infrastrukture za katoličke hodočasnike pretežno su se usmjerila na Jeruzalem upravo zato što su tamošnji lokaliteti i bili glavni ciljevi hodočašća u Svetu zemlju (usp. MORRIS 2005: 301-303; CAMPOPIANO 2012: 76).

Postavlja se pitanje je li čak i raspored međupostaja na zamišljenome putu od Jeruzalema do Hebrona bio zamišljen kao pokušaj da se hodočasničkim putem povijest Spasenja dosljedno obilježi kronološki obrnutim redosljedom. Iako sadržaj itinerara ne omogućuje da se na to pitanje bez oklijevanja potvrdno odgovori, smatram da teza o obrnuto poredanim kronološko-tematskim slojevima doista zavređuje pažljivo razmatranje. Naime, nakon (A) jeruzalemskih lokaliteta na kojima se u prvome redu komemoriraju Kristova muka, uskrsnuće i život prve Crkve, glagoljski itinerar opisuje putovanje koje je uglavnom usmjereno prema (B) lokalitetima na kojima se komemoriraju Kristovo rođenje (Betlehem) i javno djelovanje (Betanija, Jordan, Samarija). Kazivačevo se zanimanje potom usmjerava prema (C) lokalitetima koji su povezani s Ivanom Krstiteljem, a putovanje se potom dovršava u (D) Hebronu gdje se komemoriraju starozavjetni patrijarsi i Adam. Međutim, ako se usmjerimo na razinu pojedinosti, iznesena se podjela ipak može činiti donekle nategnutom. Naime, osim lokaliteta koji su vezani za Kristovu muku, uskrsnuće i ranokršćansku povijest, u Jeruzalemu se spominju mjesto pronalaska Adamove glave ( $V$ komb mêsti bi našasta gl(a)va adamova, f. 15ra), grob d(a)v(i)da

ničke zajednice, koja se najčešće uspješno prilagođavala relativno nepovoljnim uvjetima djelovanja na prostoru pod mamelučkom vlašću (usp. CAMPOPIANO 2012: 76-77, 89; JURKOVIĆ 2013: 18). Međutim, njihovi odnosi s Mamelucima zgodimice su bili i zategnuti (usp. JURKOVIĆ 2013: 11-12). Naime, usprkos tomu što su sionski franjevci vodili računa o stjecanju međukulturne obaviještenosti kao važnome preduvjetu za osiguravanje preživljavanja njihove kustodije u Svetoj zemlji, očigledno je da su neizbježan dio njihova redovničkoga svjetonazora bili i stavovi o zabludjelosti drugih religija te nekatoličkih kršćanskih vjeroispovijesti (usp. CAMPOPIANO 2012: 89). Stavovi o zabludjelosti islama kadšto su motivirali istupe kojima su sionski franjevci ugrožavali odnose svoje kustodije s jeruzalemskom mamelučkom upravom (usp. CAMPOPIANO 2012: 89), što se negativno odražavalo i na njihovu mogućnost pružanja kvalitetne podrške katoličkim hodočasnicima. Među krizama koje su bile prouzročene djelovanjem same braće iz samostana na gori Sion naročito se ističu posljedice neuspješnoga misionarskoga čina četvorice franjevaca koji su smaknuti 1391. godine nakon što su održali propovijed na arapskome jeziku kojom su čak i jeruzalemskoga kadiju poticali da se s islama obrati na kršćanstvo (usp. CAMPOPIANO 2012: 89; JURKOVIĆ 2013: 1-2, 16-17; KUŽIĆ 2013: 184). Inače, riječ je o slučaju o kojemu se višekratno pisalo i u hrvatskoj historiografiji, jer je među četvoricom tada pogubljenih franjevaca bio i Šibenčanin Nikola Tavelić. Za literaturu o toj temi vidi bilješke u JURKOVIĆ 2013: 11-13. 
krala (f. $\left.15 \mathrm{r}^{\mathrm{b}}-15 \mathrm{v}^{\mathrm{c}}\right)$, grebs krala ezoprata (f. $\left.15 \mathrm{v}^{\mathrm{d}}\right)^{31}$ i mjesta na kojima se komemorira Kristovo javno djelovanje (mêsto k'di o(t)čen(a)̌s'stvoren' bi, f. $15 \mathrm{v}^{\mathrm{d}}$ ). Isto tako, u opisu puta prema Betlehemu, koji je kršćanskim hodočasnicima bio ponajprije zanimljiv kao mjesto Kristova rođenja, spominje se grob Jakovljeve žene Rahele (i meû cr(ê)kvu i vitlêomomb e(stb) grobs rahilin', f. $\left.16 \mathrm{r}^{\mathrm{a}}\right)$, a u samome se Betlehemu pažnja posvećuje i Jeronimovu počivalištu i spiljskoj nastambi (grob's(ve)t(a)go eronima · i e(stb) peĉ gdi e stal', f. $\left.16 \mathrm{r}^{\mathrm{b}}\right)$. Nadalje, nizanje mjesta Kristova javnoga djelovanja prekida se spominjanjem događaja koji se opisuje u starozavjetnoj Knjizi o Jošui (Jš 4,1-24) (gdi s(i)ni iz(drai)l(e)vi minuše êrdanb i položiše bï [=12] kamika ke vzeše ot rêki, f. 16r ${ }^{\mathrm{b}}$ ) i Drugoj knjizi o kraljevima (2Kr 2,19-22) (naideš ednu vodu ku osladi pro(ro) kb elisei, f. $\left.16 \mathrm{v}^{\mathrm{c}}\right)$. Ipak, istovremeno treba naglasiti da su sva takva odstupanja zapravo mogla biti motivirana potrebom za racionalizacijom hodočasničkoga puta u okolnostima kada su se pojedine prostorno bliske lokacije smatrale poprištima važnih događaja iz različitih odsječaka povijesti Spasenja. ${ }^{32}$

\subsection{Komunikacija s naslovljenikom}

Među retoričkim sredstvima koja su upotrijebljena u itineraru ot er $(u)$ $s(o) l(i) m a$ i groba b(o)žiê čt(enie) (f. 15 $\mathrm{r}^{\mathrm{a}}$ ) vrijedi skrenuti pažnju na već spominjano oblikovanje komunikacijske situacije u kojoj se kazivač izravno obraća naslovljeniku u drugome licu jednine. Naime, ako se izuzme pojava oblika za drugo lice množine imperativa u prvoj rečenici nakon incipita $(V$ $\operatorname{cr}(\hat{e}) k v i$ s(veta) go groba pitaite sihb mêst', f. 15ra) i jednokratna uporaba oblika za prvo lice množine imperativa u središnjemu dijelu izlaganja (Nine se povratimo na silois ' $k u$ vodu, f. $15 \mathrm{v}^{\mathrm{c}}$ ), u izravnome obraćanju naslovljeniku redovito se pojavljuju oblici za drugo lice jednine imperativa i prezenta koji se upotrebljava u futurskome značenju (Naprid'naideš' mêsto gdi potekoše žido-

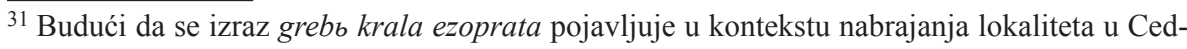
ronskoj dolini, vjerojatno je riječ o grobu judejskoga kralja Jozafata koji je »kolektivno pamćenje« često povezivalo upravo s tim prostorom (usp. ZISSU; TENDLER 2011:27*).

${ }^{32}$ Učestalost međusobne blizine starozavjetnih i novozavjetnih memorijalnih lokaliteta u Svetoj zemlji Maurice Halbwachs u knjizi La topographie légendaire des Évangiles en Terre sainte. Etude de mémoire collective (1941.) tumači kao posljedicu nastojanja ranih kršćana da naizgled afirmativnom reinterpretacijom židovskoga poimanja Svete zemlje priskrbe tradicijski legitimitet vlastitoj religiji, što se očitovalo u projekciji »legendarne topografije« »kršćanskoga kolektivnoga pamćenja « na neke od lokaliteta koji su se tada smatrali prostornim uporištima »židovskoga kolektivnoga pamćenja» (HALBWACHS 1992: 213-215, 219). 
ve za apustoli gda nesihu têlo s(ve)te $m(a)$ rie, f. $15 \mathrm{v}^{\mathrm{c}}$; I $n$ (i)ne poidi po drazi ezofatovi gore naideš' mêsto gdi vrgoše iz' gr(a)da s(veta)go êk(o)va v potokb cidron', f. $15 \mathrm{v}^{\mathrm{cd}}$; Nina poidi na vrh' mas'l'in's 'ki na polu puti naidešb s'tênu na koi g(ospo)d(i)nb stoe vidê grad' er(u)s(oli)mb i pl(a)ka, f. 15v'; propr(ê)d' naideš' mêsto gdi anj(e)l'gos 'poi prinese pal'mu, f. $15 \mathrm{v}^{\mathrm{d}} ; k(a) d a$ vlizešb $v(b)$ gr(a)d' naideš' $\operatorname{cr}(\hat{e}) k(a) v b$ s(ve)te $m(a) r i e, f .16 r^{\mathrm{a}}$; Mini $\operatorname{cr}(\hat{e}) k(a) v b$ naidešb

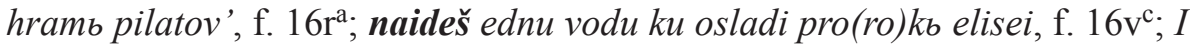
tim putem ' naideš' $k r(i) z ̌ a ~ s(v e) t(a) g o c r(\hat{e}) k(a) v b$, f. $\left.16 \mathrm{v}^{\mathrm{d}}\right)$. Sličan je retorički postupak potvrđen već na samome početku dokumentirane tradicije kršćanskih itinerara na latinskome jeziku. Naime, uvođenje vidljiva naslovljenika koji se očituje u glagolskim oblicima za drugo lice jednine potvrđeno je već u brojnim segmentima latinskoga ranokršćanskoga teksta Itinerarium Burdigalense iz 4. stoljeća u kojemu se također opisuje hodočašće u Jeruzalem (usp. ELSNER 2000: 181, 195; DUDA 2012: 93, 104). Ta je podudarnost osobito zanimljiva ako se uzme u obzir to da je riječ o postupku koji prema Jasu Elsneru nije bio tipičan za starije svjetovne antičke itinerare i periegetičku literaturu u kojima se opis puta dosljedno izlagao u trećemu licu, a naslovljenik je ostajao prikriven (ELSNER 2000: 195). Možda bi sličnost u stupnju vidljivosti naslovljenika u glagoljskome hodočasničkome itineraru i tekstu Itinerarium Burdigalense mogla biti trag tradicijskoga čuvanja stilskoga repertoara koji se oblikovao upravo u vrijeme postanka samoga žanra kojemu ta dva teksta pripadaju. Međutim, izrečena zamisao o mogućemu stilskome kontinuitetu dugoga trajanja ima tek karakter obaviještena nagađanja koje se ne može konačno potvrditi ni istraživanjem obimnijega korpusa. Naime, do pojave slične razine vidljivosti naslovljenika moglo je doći i pri sasvim neovisnome traženju djelotvorne retorike za dva tematski i namjenski srodna teksta, osobito ako se uzme u obzir da je riječ o retoričkome postupku koji se često pojavljuje i u drugim poučnim i devocionalnim srednjovjekovnim žanrovima (usp. AUERBACH 1993: 297-302; McNAMER 2010: 12)

Iako se kazivač glagoljskoga itinerara i kazivač teksta Itinerarium Burdigalense često izravno obraćaju svojim naslovljenicima služeći se glagolskim oblicima za drugo lice jednine, podrobnija usporedba Elsnerovih zapažanja o uporabi glagolskih oblika u ranokršćanskome itineraru s rezultatima analize uporabe glagolskih oblika u hrvatskoglagoljskome itineraru pokazuje da ipak postoje određene razlike u načinu na koji kazivači tih dvaju tekstova upotrebljavaju glagolska vremena i načine (ELSNER 2000: 195). Iako kazivač itinerara iz Vinodolskoga zbornika u izravnome obraćanju naslovljeniku upotrebljava isključivo prezent i imperativ, u brojnim dijelovima toga teksta obilno su zastupljene i potvrde aoristnih (mêsto gdi obraše matiê za ap (usto)la - mêsto k'di pokopan' bê s 'tipan 'prvi m(u)č(eni) kb, f. 15r'b; i tu se otvrže petar' 
$g(o s p o) d(i) n a, f$. $15 v^{c}$; edna mila ot v(it)lêoma na vstokb $k^{\prime}$ di se anj(e)lb pokaza pastiremb ot er(u)s(o)l(i)ma i tu grobs $k^{\prime} d i$ is $(u) h(r b s t) b$ v'skr(ê)si lazara, f. 16rb'; gal'gala gdi s(i)ni iz(drai)l(e)vi minuše êrdanb i položiše bï [=12] kamika ke vzeše ot rêki, f. 16r ${ }^{b}$ ) te imperfektnih glagolskih oblika (mêsto k(b)di s(ve)ta $m(a)$ riê staše poli kr'ižb. Mêsto k'di ego z'na(n)ci stoêhu s's(ve)tu mariû magdalenu, f. 15 $\mathrm{r}^{\mathrm{ab}}$; kami črevlenb na komb s(ve)ti iv(a)nb ev(a)nj(e)l(i)stb služaše misu s(ve)toi m(a)rii, f. 15r ', mês'to k'di b(la)ž(e)na m(a)riê utak'nu $g(o s p o) d(i) n a$ kada $k r(i) z ̌ b$ nesiše · trudan' $i$ unevolenb, f. 16ra ; mêsto $k$ 'di mar'ta služaše g(o)spodinu, f. 16r ${ }^{\mathrm{b}}$ ). Oblici namijenjeni izražavanju prošloga vremena redovito se pojavljuju u rečenicama koje se zavisno ili nezavisno nadovezuju na rečenice s glagolom u imperativu ili u indikativu prezenta kojim se opisuje sadašnjost ili budućnost. ${ }^{33}$ Preciznije govoreći, potvrde oblika za prošlo vrijeme susreću se uglavnom u mjesnim i relativnim rečenicama koje su podređene glavnoj rečenici s prezentskim predikatom (I v'tomb mês 'ti $\boldsymbol{e}(\mathbf{s t b})$ [=prezent] dêl ot stlpa poli ki bê isusb privezanb $i(\boldsymbol{m u}) \grave{c}(\boldsymbol{e}) \boldsymbol{n} \boldsymbol{b}$ [=aorist], f. $15 \mathrm{r}^{\mathrm{b}}$; I naprid' $\boldsymbol{e}$ [=prezent] mêsto gdi se prestavi [=aorist] $n(a) \check{s} a$ gospoê, f. $\left.15 r^{b}\right)$ te u rečenicama koje se parataktički nadovezuju na sadržaj rečenica s prezentskim glagolskim oblicima (I naprid' $\boldsymbol{e}$ [=prezent] mêsto narečemo kuripoû $i$ tu se otvrže [=aorist] petar' $g($ ospo $\left.) d(i) n a, f .15 v^{c}\right)$ ili oblicima zapovjednoga načina $(V \operatorname{cr}(\hat{e}) k v i$ s(veta) go groba pitaite [=imperativ] sihb mêst $v r^{\prime} h b$ kalbvarie $I$ I ' kom vrhu bê raspetb [=aorist] is $(u) h(r b s t)_{b} \cdot i$ vb grobb $v$ 'ki bi vloženb [=aorist] gol'gota $\cdot V$ komb mêsti bi našasta [=aorist] gl(a)va adamova I s'tl'pb komu privezanb bi [=aorist], f. 15ra ; Nine se povratimo [=imperativ] na silois 'ku vodu i tu prosvêti [=aorist] $i(s u) s b$ sl(ê) pca, f. $\left.15 \mathrm{v}^{\mathrm{c}}\right)$. Ako se osvrnemo na sadržaj rečenica u kojima se pojavljuju oblici za prošlo vrijeme, vidjet ćemo da su one isključivo namijenjene opisivanju događaja iz biblijske povijesti i ranoga kršćanstva. S druge strane, pripovijedanje o samome tijeku hodočašća kroz Svetu zemlju dosljedno se ostvaruje pomoću prezentskih i zapovjednih rečenica, čak i onda kada se s izravnoga obraćanja naslovljeniku u drugome licu prelazi na manje prisno pripovijedanje u trećem. Drugim riječima, kazivač hrvatskoglagoljskoga itinerara usmjerava tekuće pu-

${ }^{33}$ Način na koji se glagolska vremena upotrebljavaju u itineraru iz Vinodolskoga zbornika uvelike je usporediv s dosadašnjim zapažanjima o dinamičnim izmjenama vremenske perspektive u pripovijedanju Feliksa Fabrija, ulmskoga dominikanca koji je u djelu Eigentliche beschreibung der hin und wider farth zu dem Heyligen Landt gen Jerusalem, und furter durch die grosse Wüsteney zu dem Heiligen Berge Horeb Sinay podrobno opisao hodočasnička iskustva iz Svete zemlje koju je u 80 -im godinama 15. stoljeća posjetio čak dva puta (DORNINGER 2014: 425-426). Inače, pored spomenuta teksta Fabri je jeruzalemskim hodočašćima posvetio i latinski putopis Evagatorium et Terrae Sanctae, Arabiae et Egypti peregrinationem (usp. KRASIĆ 2001: 149) te vernakularna djela Gereimtes Pilgerbüchlein i Sionpilger (usp. BEEBE 2014: 75-79). 
tovanje ili planira putovanje koje tek treba započeti. Za razliku od glagoljskoga itinerara koji se prema hodočasničkome činu dosljedno odnosi kao prema željenoj bližoj ili daljoj budućnosti, Itinerarium Burdigalense u rečenicama koje pripovijedaju o samome putovanju ipak sadržava potvrde oblika ambulavimus i reversi sumus (ELSNER 2000: 195): Item ambulauimus Dalmatico et Zenofilo cons. III. kal. Iun a Calcidonia et reuersi sumus Constantinopolim VII. kal. Ian. consule suprascripto (GEYER 1898: 13). Upotrebom navedenih oblika za prošlo vrijeme kazivač ranokršćanskoga itinerara hodočašće neizravno definira kao radnju u kojoj je sudjelovao prije samoga čina pripovijedanja (ELSNER 2000: 195). Ako identitet unutartekstne instance kazivača povežemo s identitetom zbiljskoga autora itinerara, možemo pretpostaviti i to da je posrijedi opis zbiljskoga putovanja koje se prema konzulskome mandatu iz prethodnoga citata može datirati u 333. godinu (ELSNER 2000: 183-184; usp. DUDA 2012: 93). Ipak, iako je putovanje iz teksta Itinerarium Burdigalense predstavljeno kao vremenski određen događaj iz prošlosti, treba povesti računa i o tome da čak i taj tekst učestalom uporabom prezentskih oblika i izravnim obraćanjem naslovljeniku »na stanovit način svog čitatelja poziva da putuje zajedno s njim i čini mu Svetu zemlju dostižnom «(DUDA 2012: 104; usp. ELSNER 2000: 195). Međutim, potonja funkcija teksta znatno je naglašenija u itineraru iz Vinodolskoga zbornika u kojemu se isključivo i govori o naslovljenikovu putovanju koje se tek treba dogoditi.

\subsection{Funkcija}

Hrvatskoglagoljski itinerar iz Vinodolskoga zbornika nije bio zamišljen kao praktični vodič za snalaženje u Svetoj zemlji, iako nerijetko donosi obavijesti o udaljenostima među pojedinim lokalitetima koje se iskazuju u miljama (ot er(u)s(o)l(i)ma do vitleoma mile $\cdot g \cdot[=4]$ i e(stb) polb puti s(ve)ti iliê, f. 16ra ; I e(stb) edna mila ot v(it)lêoma na vstokb $k^{\text {'d }}$ i se anj(e)lb pokaza

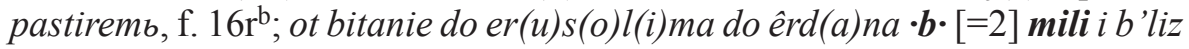
e(stb) rêka ed'na, f. 16r'b; ot rêki ed'na mila e(stb) mêsto k'di bi is(u)h(rbst)b

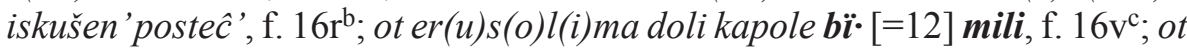
er $(u) s(o) l(i) m a \cdot b \cdot[=2]$ mili ot zapada mêsto v kom se rodi iv'nb $k r(b) s(t i) t(e) l$ ',

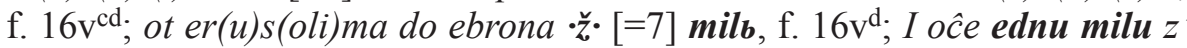
eb 'rona greduĉ v' er(u)s(o)l(i)mb est' edna dr(u)ga, f. 16v') i streličarskim domašajima ( $i$ ot tud' $\cdot \boldsymbol{b} \cdot[=2]$ strilaê ed'va gdi priizdi is $(u) h(r b s t) b$ na osleti, f. $15 v^{d}$ ). Naime, praktičan kršćanski vodič za snalaženje u Svetoj zemlji zasigurno bi uz obavijesti o udaljenostima među lokalitetima sadržavao i obilje obavijesti o okolnostima koje proizlaze iz činjenice da je taj prostor bio pod upravom Mamelučkoga Sultanata. Međutim, hrvatskoglagoljski itinerar 
isključivo spominje mjesta koja su se smatrala svetima u kršćanskome $\gg k o-$ lektivnome pamćenju « (HALBWACHS 1992), a na muslimansku prisutnost u Svetoj zemlji upućuje tek u spomenu jedne od dviju crkava posvećenih Ivanu Krstitelju: $i$ ondi sta $\cdot \boldsymbol{b} \cdot[=2]$ cr(ê)kvi s(ve)t(a)go ivana edna na sl'nčb zapad' $i$ vn(e)i mu e gl(a)va usičena i drže û h(rbst)bêne a v'drugoi bi položen'i drže $\hat{u}$ sracini $\left(\right.$ f. $\left.16 \mathrm{v}^{\mathrm{c}}\right)$. Drugim riječima, hrvatskoglagoljski itinerar je primarno usmjeren na oblikovanje prostora u kojemu se treba ostvariti kršćanska hodočasnička pobožnost. Međutim, takvo predstavljanje Svete zemlje istovremeno je moglo imati i ideološku funkciju. Naime, potiskivanje muslimanske prisutnosti u hrvatskoglagoljskom itineraru moglo bi biti odjek križarskoga »diskurza o Svetoj zemlji« koji naglašava kršćansko pravo na raspolaganje Jeruzalemom i drugim svetim mjestima, a osobito su ga njegovali tekstovi sionskih franjevca od kojih su putnici i dobivali većinu obavijesti potrebnih za snalaženje u tome prostoru (CAMPOPIANO 2012: 89).

Iako već i sadržaj hrvatskoglagoljskoga itinerara upućuje na zaključak da taj tekst nije bio primarno namijenjen olakšavanju orijentacije u zbiljskome geografskome prostoru, dodatnom potvrdom te pretpostavke može se smatrati i kontekst njegova zapisivanja u Vinodolskome zborniku. Naime, budući da je itinerar u tome zborniku zapisan među nizom poučnih tekstova (ŠTEFANIĆ 1970: 6), čini se da je i sam mogao biti ponajprije shvaćen kao poučni tekst koji pamćenje povijesti Spasenja temelji na prostornim mnemotehničkim strategijama koje su imale važno mjesto u srednjovjekovnoj kulturi (usp. CARRUTHERS 1998: 10-23, 40-44; CARRUTHERS 2008: 76-78). Takav je pristup pamćenju bio osobito prikladan za meditaciju u obliku »virtualnih hodočašća (usp. RICHARD 1996: 683; RUDY 2000; MORRIS 2005: 345; RUDY 2014), ${ }^{34}$ koja su se u pojedinim srednjovjekovnim tekstovima vrednovala jednako kao i tjelesna, kao što se može vidjeti na primjeru engleskoga itinerara For the Ynformacion of that most blessed viage to the Holi Citee of Hierusalem: »To whom and to alle other Cristians deliteng to visite that most reverend holi citee of Hierusalem here terrestrialle mylitant or to hyre speke or reede of that blessed elect place I devoteli praie oure glorious Lorde Godde Almyghti Jesu Crist to graunt them habunduant grace in this lyfe present and, after that, perpetualle ioye yn the celestialle Hierusalem tryumphaunt« (BREFELD 1985: 105).

\footnotetext{
${ }^{34}$ Iako hrvatskoglagoljski itinerar obiluje podatcima o prostornim udaljenostima među hodočasničkim lokalitetima, takve su se obavijesti često pojavljivale i u tekstovima koji su nedvojbeno bili namijenjeni »virtualnim hodočašćima«, što bi se moglo povezati s raširenim vjerovanjem da »mjere svetih mjesta same po sebi imaju mističnu vrijednost« (MORRIS 2005: 58; usp. MORRIS 2005: 60-61).
} 


\section{LATINSKI ILI ROMANSKI PREDLOŽAK GLAGOLJSKOGA ITINERARA}

Proučavatelji kasnorednjovjekovnih itinerara i putopisa o Svetoj zemlji redovito naglašavaju da je većina tekstova u tome kvantitativno bogatu korpusu sadržajno i stilski jako srodna (usp. MORRIS 2005: 312). Sadržajne sličnosti među srednjovjekovnim itinerarima i putopisima navele su Josephie Brefeld na pretpostavku da se većina tih tekstova temelji na nekom zajedničkom "prototipnom vodiču « (BREFELD 1994: 10-11; usp. WESTREM 1997: 116; MORRIS 2005: 312), što je pokušala dokazati kvantitativnim metodama u monografiji A Guidebook for the Jerusalem Pilgrimage in the Late Middle Ages. A Case for Computer-Aided Textual Criticism (BREFELD 1994). Istražujući osamnaest proizvoljno odabranih tekstova o Svetoj zemlji Brefeld je utvrdila da se u njima najčešće pojavljuju isti hodočasnički lokaliteti, što smatra potvrdom njihova zajedničkoga podrijetla (usp. WESTREM 1997: 118). Međutim, njezino istraživanje naišlo je na oštre kritike u medievističkim krugovima među kojima osobito valja skrenuti pozornost na recenziju Scotta D. Westrema, koji je kritizirao proizvoljnost $\mathrm{u}$ autoričinu odabiru korpusa i dvojbenu relevantnost podataka na koje se Brefeld oslonila (WESTREM 1997: 118). Naime, Westrem naglašava da su pri analizi podataka o prisutnosti pojedinih lokaliteta u odabranim tekstovima zanemareni redoslijed pojavljivanja tih lokaliteta te varijacije u toponimima i deskriptivnim odrednicama kojima se na te lokalitete upućivalo (WESTREM 1997: 118-119). Nadalje, o neuvjerljivosti tumačenja pojave istih lokaliteta kao dokaza postojanja »prototipnoga vodiča« svjedoči i to što je Brefeld potpuno zanemarila alternativnu mogućnost da se ista pojava protumači kao posljedica uhodanosti hodočasničke prakse..$^{35}$

Iako je zamisao o zajedničkome tekstualnome ishodištu čitava korpusa hodočasničke literature o Svetoj zemlji očigledno problematična, poznato je da su se pisci itinerara i putopisa doista često služili obavijestima iz tekstova svojih prethodnika (MORRIS 2005: 312). Kao što je to slučaj sa znatnim dijelom hrvatskoglagoljske zborničke proze, ni tekst hodočasničkoga itinerara iz Vinodolskoga zbornika vjerojatno nije izvorno sastavljan na hrvatskome

${ }^{35}$ Naime, sličnosti među hodočasničkim itinerarima proizlaze iz zajedničkoga oslonca u kršćanskome »kolektivnom pamćenju«, a zasigurno su ih pothranjivali i popisi indulgencija koje su se mogle dobiti na točno određenim mjestima (usp. RUDY 2000: 496). Zanimljivo je da se stabilnost hodočasničke prakse može uočiti i u tekstovima suvremenih pisaca. Naime, uspoređujući Putovanje k Jeruzolimu god. 1752. Jakova Pletikose »s postmodernističkim Putom u Jeruzalem Spomenke Podboj« Cvijeta Pavlović zaključuje da se »u većem [...] dijelu ta dva putopisa podudaraju u redoslijedu razgledavanja prostora, [...] što znači da se od Pletikosina vremena do XX. i XXI. stoljeća hodočasničko-turistički itinerarij nije znatnije mijenjao« (PAVLOVIĆ 2010: 148). 
jeziku bez izravna oslanjanja na izvore pisane drugim jezicima. Hipoteza o jednome ili više nepoznatih stranih predložaka prije svega se temelji na abduktivnome traženju uvjerljivih objašnjenja dvaju nejasnih mjesta na glagoljskome popisu hodočasničkih lokaliteta, a riječ je o izrazu ot kapole (f. $16 \mathrm{v}^{\mathrm{c}}$ ) te o upućivanju na mjesto jednoga povijesno nepotvrđena vladarskoga ukopa u blizini Makpele i Hebrona (I ondi blizu mêsto gdi leži c(êsa)rb damasinuš') (f. $16 v^{d}$ ). Pretpostavljajući zasnovanost hrvatskoglagoljskoga itinerara na latinskoj ili romanskoj hodočasničkoj prozi, prvo ću nejasno mjesto protumačiti kao odraz horonima Decapolis ili Decapoli, a potom ću izraz c(êsa)rb damasinuš ' protumačiti kao pogrešku koja je vjerojatno motivirana sličnostima među pojedinim gramatičkim oblicima latinskih i romanskih naziva za geografski pojam regio (lat.) i vladarsku titulu rex (lat.).

Izraz ot kapole spominje se u kontekstu izlaganja o samarijskim lokalitetima poput grada Sihara i Jakovljeva zdenca, te brdā Gerezim i Ebal, koji se prema glagoljskome itineraru nalaze $v$ depokali: I $v$ depokali ed(a)nb grad' sikarii e(stb) z(a)stavlenb meû dvima vrhoma ed(a)n'e garazimb a drugi ebalb i bl(i)zu vlazeĉi v gr(a)d ot strani er(u)s(o)l(i)ma e(stb) ed(a)n studenacb narečeni êkovalb na kom govori i(su)sb samaritanê ot kapole suprotiv' aciû [dubitanter!] d'vi milie vladanû imenemb sabastemb (f. $16 \mathrm{v}^{\mathrm{c}}$ ). Budući da u Samariji i okolici nema važnijih toponima koje bi se moglo povezati s izrazom ot kapole, postavlja se pitanje nije li riječ o izobličenju toponima koji je prvotno izričito upućivao na istu geografsku cjelinu kao i prethodno spomenuti izraz $v$ depokali. S jedne strane, povezivanje drugdje neovjerena horonima Depokala s izrazom ot kapole navodi na pomisao da bi Depokala mogla biti izobličena hrvatska inačica toponima Decapolis ili Decapoli, nastala zbog nehotične zamjene položaja drugoga i trećega sloga u imenu. S druge strane, pretpostavka o prvotno zajedničkim referentima spornih dvaju toponima omogućuje da se izraz »ot kapole« protumači kao posljedica pogrešnoga razumijevanja horonima Decapolis ili Decapoli, do čega je moglo doći zbog shvaćanja toga imena kao sveze latinskoga ili romanskoga prijedloga de s imenicom, pri čemu je nemoguće razabrati radi li se o izravnome propustu hrvatskoga pisca ili tek o njegovoj reakciji na bjelinu među riječima koja je greškom uvedena unutar latinske ili romanske rukopisne tradicije koja je rezultirala predloškom na kojemu se temeljio hrvatski tekst.

Prije nego što se pristupi raščlambi pojma $c(\hat{e} s a) r b$ damasinuš , potrebno je preduhitriti i jedan mogući geografski prigovor iznesenome tumačenju podrijetla izraza ot kapole. Interpretacija toga izraza kao posljedice pogrešna prepisivanja ili prevođenja horonima Decapolis ili Decapoli može se činiti dvojbenom zato što se u komentiranim redcima govori o samarijskim lokalitetima koji se nalaze zapadno od Jordana, a ne o mjestima koja historijska 
geografija obično povezuje s dekapolskim prostorom. Naime, kada se pojam Dekapolis upotrebljava u kontekstu historijske geografije biblijskih prostora, obično se pomišlja na krajeve pridružene nekome od desetak gradova koji su se pretežno nalazili istočno od Jordana i Galilejskoga jezera, a povezuje ih vrlo naglašen grčko-rimski kulturni superstrat, koji se, budući da se većina dekapolskih gradova urbanizirala tek $u$ helenističko vrijeme, može jasno prepoznati i u karakteristikama arheoloških tragova (usp. PARKER 1975: 438-441; MUSSIES 1997: 270-272; WEIMAR 1997: 53). ${ }^{36}$ Iako se jedan od dekapolskih gradova, Skitopolis ili Bet Šan, ipak nalazio zapadno od rijeke Jordan i u relativnoj blizini krajeva oko samarijskih brdā Gerezim i Ebal, moderna historijska geografija novozavjetnih prostora ne poznaje pisana vrela iz kojih bi se dalo iščitati da su ta samarijska brda i obližnja naselja u antici bila poimana kao dijelovi Dekapolisa (PARKER 1975: 440; MUSSIES 1997: 270-272). Međutim, na temelju izostanka bilo kakva stvarnoga preklapanja između novozavjetne Samarije i Dekapolisa ipak se ne može uvjerljivo pobiti ovdje iznesena teza prema kojoj su redci o Siharu, Jakovljevu zdencu i samarijskim brdima u nekim fazama rukopisne tradicije latinskoga ili romanskoga predloška hrvatskoglagoljskoga itinerara doista izravno proglašavali te lokalitete dijelovima dekapolskoga prostora. Naime, anticipirani se geografski prigovor na općenitoj razini može relativizirati tako što će se ukazati na popriličnu zbrku u načinu na koji su srednjovjekovni pisci razgraničavali i imenovali pojedine regionalne cjeline. ${ }^{37}$ Osim toga, na partikularnijoj se razini može upozoriti na

${ }^{36}$ Ovdje se o Dekapolisu govori kao o kulturnome arealu, a ne kao o politički ustrojenoj geografskoj cjelini. Naime, iako bibličari i povjesničari staroga vijeka često definiraju Dekapolis kao »savez« ili »udruženje« (usp. WEIMAR 1997: 53; JERUZALEMSKA BIBLIJA 2001: 1398), čime se implicira postojanje nekog oblika zajedničke političke platforme dekapolskih gradova (usp. PARKER 1975: 437-438), S. Thomas Parker naglašava da ti gradovi nisu djelovali koordinirano čak ni u kriznim vremenima, što znači da je pojam Dekapolis vjerojatno funkcionirao tek kao naziv za specifičan kulturni areal na istočnome rubu Rimskoga Carstva (PARKER 1975: 440-441).

${ }^{37}$ Nedosljednosti u srednjovjekovnim tekstovima geografskoga sadržaja često proizlaze iz nepostojanja jasno oblikovane srednjovjekovne geografske paradigme. Naime, srednjovjekovni pisci nisu imali ujednačen pristup prevladavanju raskoraka između informacija koje su mogli pročitati u tekstovima pojedinih geografskih autoriteta i onih koje su mogli prikupiti tijekom vlastitih putovanja (usp. WRIGHT 1925: 255-257, 360; RICHARD 1996: 684). Odabir između pisane tradicije i suvremenoga iskustva ovisio je o nizu okolnosti spisateljskoga rada poput razine piščevih osobnih kontakata s opisivanom sredinom, dostupnosti geografske literature i informanata, naravi piščeva obrazovanja, njegovih predodžbi o očekivanjima ciljane publike te zamišljene namjene teksta (WRIGHT 1925: 255-257; usp. DUDA 1998: 13; DORNINGER 2014: 424-425). Pritom nedosljednosti u srednjovjekovnim regionalnim podjelama i pokušajima smještaja pojedinih toponima proizlaze i odatle što su geografi skloni afirmaciji pisane tradicije nerijetko u sinkronijskome ključu čitali izvore koji govore o geografskim podjelama iz različitih povijesnih razdoblja. Nadalje, kada je riječ o 
činjenicu da se u nizu srednjovjekovnih izvora Dekapolis doista smješta podalje od neposredne okolice Skitopolisa i transjordanskoga prostora u kojima se za vrijeme Kristova javnoga djelovanja nalazio dekapolski kulturni areal. Iako zasada nisu poznati drugi tragovi predaje koja bi Jakovljev zdenac i Sihar smještala unutar Dekapolisa, u više je važnijih srednjovjekovnih tekstova o Svetoj zemlji ovjeren smještaj Dekapolisa sjeverozapadno od Galilejskoga jezera. Tako npr. Jacques de Vitry u djelu Historia Hierosolymitana iz prve polovice 13. st. granicu Dekapolisa proteže sve do grada Sidona na Sredozemnome moru (JACQUES DE VITRY 1896: 24). Na autoritet Jacquesa de Vitryja pred kraj 13. st. izravno se pozvao njemački dominikanac Burchard de Monte Sion u djelu Descriptio Terrae Sanctae (BURCHARD OF MOUNT SION 1896: 40-41). Na tragu svojega prethodnika Burchard proteže Dekapolis sve do Sidona, a zatim nabraja i imena deset gradova koji su navodno motivirali nastanak horonima Dekapolis (BURCHARD OF MOUNT SION 1896: 41). Međutim, među gradovima s Burchardova popisa samo se za Skitopolis ili Bet Šan može reći da je povijesno bio jedan od dekapolskih gradova (usp. PARKER 1975: 438), dok je u preostalih devet slučajeva riječ o imenima galilejskih naselja (usp. BURCHARD OF MOUNT SION 1896: 41). Nabrajanje niza galilejskih naselja pri definiranju prostorne okosnice Dekapolisa ovjere-

kršćanskim opisima Svete zemlje, problemi nastaju i zbog toga što su kanonska evanđelja povremeno bila poimana kao autoritativni izvori geografskih podataka o bliskoistočnim krajevima (WRIGHT 1925: 43; usp. HARVEY 1996: 390), unatoč tomu što ti tekstovi nerijetko obiluju maglovitim i traduktološki prijepornim zemljopisnim odrednicama (usp. MUSSIES 1997). Naposljetku, zbrka u određivanju smještaja pojedinih geografskih regija može se povezati i s optjecajem velikoga broja nevjerodostojnih kartografskih prikaza (usp. WRIGHT 1925: 247). S jedne strane, srednjovjekovni su se zemljovidi i sami često oslanjali na podatke iz nepouzdanih tekstova poput Prirodoznanstva (lat. Naturalis historia) Plinija Starijega, različitih tipova srednjovjekovnih enciklopedija ili odjeka tih znanja u romansiranim opisima Aleksandrovih osvajačkih pothvata (HARVEY 1996: 390). S druge strane, za razliku od modernih kartografa koji u većini slučajeva nastoje u smanjenome mjerilu što točnije predočiti rezultate relativno preciznih mjerenja i izračuna stvarnih prostornih odnosa, izrađivači srednjovjekovnih zemljovida ne samo da najčešće nisu raspolagali podjednako podrobnim i preciznim podatcima o prostornim udaljenostima, nego im je u većini tipova karata simboličko predstavljanje prostora bilo daleko važnije od vjerodostojnoga predočavanja razmjera među prostornim veličinama (usp. WRIGHT 1925: 247-254; HARVEY 1996: 388-389). Ta »drugost« srednjovjekovne kartografije možda se najjasnije očituje u činjenici da su mnogi srednjovjekovni kartografi regijama manje površine posvećivali nerealno velik udio površine zemljovida ako su te regije smatrali bitnima (WRIGHT 1925: 248-249). Zanimljivo je da spomenuto srednjovjekovno kartografsko načelo jako podsjeća na praksu tadašnjih likovnih majstora koji su kroz najveći dio srednjega vijeka odnose među ljudskim likovima prikazivali u »ikonografskoj perspektivi« u kojoj »veličina lika ne ovisi o njegovu mjestu u prostoru [...], već je ta veličina funkcija ocjene njegova značenja - što je lik važniji, to će biti i prikazan većim« (IVANČEVIĆ 1979: 80). 
no je i u nizu nešto mlađih srednjovjekovnih tekstova poput prokrižarskoga traktata Secreta fidelium Crucis Marina Sanuda Torsella iz prve polovice 14. st. (MARINO SANUDO TORSELLO 2011: 394) te petnaestostoljetnih putopisa Descriptio Terrae Sanctae Johannesa Polonera (JOHN POLONER 1894: 24) i Liber peregrinationis Jakova iz Verone (IACOBUS VERONENSIS [s.a.]). Ukratko, budući da se srednjovjekovni pokušaji ubikacije Dekapolisa tek rubno podudaraju s povijesnim položajem toga areala u Kristovo vrijeme, ne postoje geografski razlozi za odbacivanje ovdje predložena tumačenja izraza ot kapole kao pogreške u prepisivanju ili prevođenju horonima Decapolis ili Decapoli.

Budući da izvođenje abduktivnih zaključaka o stranome predlošku nije osobito uvjerljivo kada se temelji na analizi samo jednoga izraza, upravo izneseni argument upotpunjujem tumačenjem postanka izraza c(êsa)rb damasinuš' koji se također može uvjerljivo objasniti uspostavom hipoteze o latinskome ili romanskome predlošku hrvatskoga itinerara. Posrijedi je izraz koji se pojavljuje u dijelu itinerara u kojemu se nabrajaju lokaliteti u okolici Hebrona: I v' eb(ro)ni su ova mesta · Prvo peĉ' dupla in'di e pokopan' avram'i isakb i êkov' $i$ s' svoimi ženami e sara reveka liê · I ne puĉâu v'nutar h(rbst)bênb - I ondi b'lizu mêsto gdi leži c(êsa)rb damasinuš · in'di bi adam stvoren' (f. $16 v^{d}$ ). Spomen takva vladarskoga ukopa u predstavljanju hebronskoga kraja privlači pozornost ne samo zato što takav ukop u blizini Hebrona nije objektivno ovjeren nego i zato što izvan ovdje analizirana glagoljskoga teksta nije potvrđen ni kao tema neke poznatije predaje. Osim toga, samo spominjanje takva ukopa upadljivo bi odstupalo od uobičajenih tematskih preokupacija kazivača glagoljskoga itinerara, jer u preostalim dijelovima toga teksta u kazivačev interesni obzor ulaze isključivo mjesta koja su se pamtila kao poprišta najvažnijih događaja iz biblijske i kršćanske povijesti. Pri tumačenju postanka izraza c(êsa)rb damasinuš' svakako vrijedi obratiti pozornost na činjenicu da glagoljski itinerar u istu hebronsku koordinatu postavlja i stvaranje čovjeka (in'di bi adam stvoren', f. 16v $\mathrm{v}^{\mathrm{d}}$ ). Važnost poveznice između spornoga izraza c(êsa)rb damasinuš' i predaje o mjestu Adamova stvaranja proizlazi odatle što srednjovjekovne bibličarske rasprave i opisi Svete zemlje često povezuju oblikovanje Adamova tijela od praha zemaljskoga s lokalitetom koji se naziva ager ili campus Damascenus (HILHORST 2007). Budući da su stvaranje prvoga čovjeka i lokalitet ager Damascenus često bili smještani upravo u hebronski kraj, s razlogom se može pretpostaviti da je glagoljaševa uporaba izraza c(êsa)rb damasinuš' na neki način povezana s izrazima ager odnosno campus Damascenus (usp. HILHORST 2007: 131, 133-136, 138-139). ${ }^{38}$ Osim

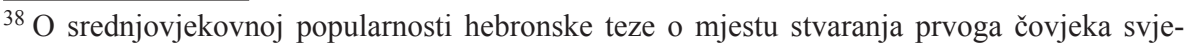
doči i njezina pojava u često prepisivanim i prevođenim pregledima popularizirane teolo- 
navedenih izraza, u pričama i teološkim raspravama o Adamovu stvaranju ponekad se pojavljuje i izraz regio Damascena (usp. HILHORST 2007: 138). Iako se tim izrazom daleko češće upućivalo na područje oko grada Damaska, u polihistorijskome djelu Otia imperalia seu Liber de mirabilibus mundi, koje je u drugome desetljeću 13. st. napisao Gervazije iz Tilburyja, konstrukcija in regione Damascena odnosi se upravo na hebronski kraj (GERVASIUS VON TILBURY 1856: 1; HILHORST 2007: 138). Budući da u latinskome jeziku i njegovim romanskim potomcima pojedini gramatički oblici imenica koje označavaju geografski pojam regio (lat.) i vladarsku titulu rex (lat.) imaju sličan izraz, Gervazijev tekst omogućuje oblikovanje hipoteze prema kojoj je izraz c(êsa)rb damasinuš’ bio ili izražajnom sličnošću motivirana greška u prevođenju izraza regio Damascena ili posljedica srodne pisarske greške koja se mogla dogoditi već u transmisiji nepoznatoga latinskoga ili romanskoga teksta kojim se služio hrvatski pisac.

\section{ZAKLJUČAK}

Tekst ot er(u)s(o)l(i)ma i groba b(o)žiê čt(enie) $\cdot k(a) p(i) t(u l b)$ zapisan na listovima $15 \mathrm{r}^{\mathrm{a}}-17 \mathrm{r}^{\mathrm{a}}$ Vinodolskoga zbornika opisuje hodočašće po Svetoj zemlji i jedini je poznati itinerar u hrvatskoj srednjovjekovnoj književnosti. Strani predložak toga teksta nije pronađen, ali je utvrđeno da se njegov pisac služio jednim ili s više stranih predložaka latinskoga ili romanskoga podrijetla. Zbog svoje jedinstvenosti u hrvatskome srednjovjekovnome korpusu zanimljiv je izvor za književnu »iterologiju« i proučavanje konstrukcija književnoga prostora. Unatoč tome, hrvatskoglagoljski je itinerar u kroatističkoj filologiji ostao nezamijećen, što bi se moglo povezati s neodređenošću njegova opisa u Štefanićevu katalogu Akademijinih glagoljskih rukopisa (ŠTEFANIĆ 1970: 6). Iako je u historiografiji zabilježen usputni pokušaj povezivanja toga teksta s hodočašćem Nikole IV. Frankapana iz 1411. godine (KUŽIĆ 2013: 168), tu interpretaciju ne opravdavaju ni sadržaj itinerara ni njegov rukopisni kontekst.

gije poput Elucidariuma Honorija Augustodunensisa ili tim tekstom potaknutih Lucidara, koji su - sudeći po proširenju teološke osnovice starijega Elucidariuma velikim rasponom svjetovnih znanja - najvjerojatnije bili usmjereni prema još široj publici. Usp. IVŠIĆ 1949: 105-106; HERCIGONJA 1975: 418; KAPETANOVIĆ 2010: 4-5. Za potvrde hebronske teze u hrvatskim prijevodima Elucidarija i Lucidara vidi: IVŠIĆ 1949: 143; NAZOR 2001: 98; KAPETANOVIĆ 2010: 15. Osim hebronske teze, koju je zastupao niz važnih crkvenih autoriteta poput svetoga Jeronima, Izidora Seviljskoga i Tome Akvinskoga (HILHORST 2007: 134), Anthony Hilhorst spominje još damašćansku i jeruzalemsku tezu (HILHORST 2007: 132-133, 136-140). Navedenim tezama treba pridodati i betlehemsku, koja je ovjerena u pojedinim latinskim inačicama apokrifa Život Adama i Eve (TURKALJ 2006-2007: 589). 
S jedne strane, riječ je o uopćenu tekstu u kojemu anonimni kazivač neimenovana naslovljenika obavještava o redoslijedu posjećivanja hodočasničkih lokaliteta u Svetoj zemlji. S druge strane, itinerar je u Vinodolskome zborni$k u$ zapisan među nizom poučnih tekstova i bez bilježaka koje bi spominjale upravo hodočašće Nikole IV. Frankapana (ŠTEFANIĆ 1970: 6), dok je sama praksa hodočašćenja u Jeruzalem bila potvrđena i među glagoljaškim klerom (RUNJE 2012: 76).

Činjenica da se u opisu zamišljena hodočašća samo jedanput spominju muslimani u Svetoj zemlji upućuje na zaključak da hrvatskoglagoljski itinerar nije bio pragmatični hodočasnički vodič. S obzirom na kontekst zapisivanja toga itinerara među poučnim tekstovima i zaobilaženje spominjanja mamelučke vlasti nad Svetom zemljom, može se reći da glagoljski itinerar promiče srednjovjekovni zapadnjački konstrukt Svete zemlje kao prostora koji ponajprije ima važno mjesto u kršćanskome »kolektivnome pamćenju« zbog čega se vjerovalo da bi isključivo kršćani trebali njime i raspolagati (usp. CAMPOPIANO 2012: 89). Prema tome, iako se hrvatskoglagoljski itinerar ne može opravdano povezati s određenim srednjovjekovnim putovanjem, posrijedi je vrijedna potvrda o strategijama prostornoga kodiranja kršćanskoga »kolektivnoga pamćenja« povijesti Spasenja, koju je predloženo hodočašće trebalo komemorirati putem od Jeruzalema kao mjesta Kristove muke do Hebrona kao mjesta Adamova stvaranja. Pritom valja naglasiti da se ta komemoracija mogla ostvarivati i u obliku virtualnoga hodočašća, a ne nužno u stvarnome prostoru Svete zemlje.

\section{TRANSLITERACIJA}

Hrvatskoglagoljski itinerar ot er (u)s(o)l(i)ma i groba b(o)žiê čt(enie) $\cdot k(a) p(i) t(u l b)$ (CVinod, ff. 15r $\mathrm{r}^{\mathrm{a}}-17 \mathrm{r}^{\mathrm{a}}$ ) preslovljen je na latinicu po standardima Staroslavenskoga in-

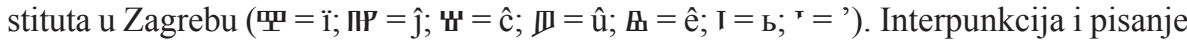
velikoga slova nisu modernizirani, nego odražavaju stanje u izvorniku. Rubricirani dijelovi izvornika preneseni su masnim slovima, ali dublete slova, ligature, superskript, title te izvorna prelamanja redaka nisu posebno označeni. Kraćenja su razriješena u oblim zagradama. Označavanje jera (ь) u razriješenim dijelovima riječi temelji se na standardima Znanstvenoga centra izvrsnosti za hrvatsko glagoljaštvo, što znači da se $b$ bilježi samo uz slogotvorne $r$ i $l$ te na završetku riječi. Radi lakšega čitanja uvedene su bjeline među riječima i na onim mjestima gdje ih u izvorniku nema. Priređivačke konjekture o sadržaju oštećenih i teško čitljivih mjesta, položaj lakuna i tumačenje glagoljskih brojeva arapskima i druge priređivačke napomene donose se u uglatim zagradama. Osim toga, u uglatim se zagradama označava i položaj pojedinih dijelova teksta unutar rukopisa. 
$\left(15 r^{a}\right)$ ๆ ot er(u)s(o)l(i)ma i groba b(o)žiê čt(enie) $\cdot k(a) p(i) t(u l b) \cdot V$ cr(ê)kvi s(veta)go groba pitaite sihь mêst' vr'hь kalıvarie · I v' komb vrhu bê raspetь is(u)h(rbst)ь · i vь grobь v' ki bi vloženь gol'gota · V komь mêsti bi našasta gl(a)va adamova · I s'tl'pь komu privezanь bi - Mêsto v' komь naide s(ve)ta elena križb g(ospo)d(a)nь $\cdot$ Mêsto k'di bi i(su)sь dr'žanь dokle križb svrišie $\cdot$ Mêsto k(a)di osipь i nikudimb oplakasta têlo isusovo $\cdot$ mêsto k(a)di s(ve)ta m(a)riê staše poli križb $\cdot$ Mêsto k'di ego z'na(n)ci sto(15rb)êhu s' s(ve)tu mariû magdalenu • Mêsto gdi se pokaza is(u)h(rbst)b magd(a)lêni po v'skrseniû · i g'reduĉi na vr(ь)hь sionь ·e [ $[=6]$ turan' davidovih' pri puti i naprid' e(stb) cr(ê)k(a)vb s(veta)go êkova i v' nei mu e gl(a)va usičena i e(stb) na vr'hu sions cr(ê)k(a)v' imenemb s(ve)ti sp(a)sitelb naiprva · i ona $\operatorname{cr}(\hat{e}) \mathrm{k}(\mathrm{a}) \mathrm{vb}$ bi hram' anic'ta [confusum!] kaifasova k' k(o)mu bi is(u)h(rbst)b popelanь $\cdot \mathbf{I}$ v' tom' hrami dr'žan v'su noĉb · I v tom' hrami se · otvrže petar' g(ospo)d(i)na - I v' tomb mês'ti e(stb) dêl ot stlpa poli ki bê isusb privezanı i (mu)č(e)nь I naprid' e mêsto gdi se prestavi n(a)ša gospoê - oĉe e(stb) kami črevlenь na komb s(ve)ti iv(a)nь ev(a)nĵ(e)l(i)stb služaše misu s(ve)toi m(a)rii · oĉe mêsto v(b) komь v komь [sic!] gos'poê s(ve)ta m(a)riê veliko lêtb s'ta po v'zneseniû - mêsto g'di obraše matiê za ap(usto)la · Mêsto k'di pokopan' bê s'tipan' prvi m(u)č(eni)kb i e(stb) gro(15v' $)$ b d(a)v(i)da krala $\cdot$ Mêsto gdê pride s(ve)ti d(u)hь vrhu ap(usto)lb · Mêsto k'di is(u)h(rbst)b večera sь ap(usto)li · i umi imb noge i v tomb mêsti imь se pokaza d'vakrat' - po v'skrseni svoemb stoeĉim' dvaromb zatvorenim' i rek'šu mir' v(a)mb · tomi otkriv'šu rane · Naprid' naideš' mêsto gdi potekoše židove za apustoli gda nesihu têlo s(ve)te m(a)rie · i ê niki ot nih' nosila i tudi emu ruka us'hanu i za m(o)l(it)vu b(la)ž(e)n(a)go petra zdrav' bi - I naprid' e mêsto narečemo kuripoû i tu se otvrže petar' g(ospo)d(i)na i pl(a)ka gorko · Oĉe e str(a)nь vrha akel'demaks skuplen' bi za $\cdot \hat{\jmath} \cdot[=30]$ srebr(b)nik' za ne bi prodan' is $(\mathrm{u}) \mathrm{h}(\mathrm{rbst}) \mathrm{b} \cdot$ Nine se povratimo na silois'ku vodu i tu prosvêti i(su)sb sl(ê)pca $\cdot$ I n(i)ne poidi po draz(15vd)i ezofatovi gore naideš' mêsto gdi vrgoše iz' gr(a)da s(veta)go êk(o)va v potokb cidron' · i ot(to)le ne potečet' I I tu grobs krala ezoprata · i naprid' mêsto k' di êše is(u)h(rbst)a mêsto k'di pot' i kr(b)v' padaše ot is(u)h(rbst)a · I tu grobb s(ve)te $\mathrm{m}(\mathrm{a})$ rie $\mathrm{v}$ cr(ê)kvi · Nina poidi na vr'h' mas'l'in's'ki na polu puti naidešb s'tênu na koi g(ospo)d(i)nь stoe vidê grad' er(u)s(oli)mb i pl(a)ka i propr(ê)d' naideš' mêsto gdi anj(e)l' gos'poi prinese pal'mu i nades'no e cr(ê)k(a)vb $\cdot s$ ke is(u)h(rbst)b · zlize na n(e)bo · mêsto k'di o(t)čen(a)š' stvoren' bi · Mêsto $\mathrm{k}(\mathrm{a}) \mathrm{di}$ vêruemb stvoren' bi · I nalivo vr(b)ha galilêê gdi se pokaza ·aï· [=11] ap(usto)lu $\cdot$ i ot tud' $\cdot \mathbf{b} \cdot[=2]$ strilaê ed'va g'di priizdi is(u)h(rbst)b na osleti · povrativ' se v' er(u)solimь pred' gradoms mêsto gdi pob'en' bi stipanь · I nalivo vrata $\cdot$ ot templa g(ospo)dna železo[m] (16ra) [...] pob'ena k'a do suda ne [otvore]t' se g(ospo)d(i)nь zatvoril' e e(stb) na cvit'nicu · K(a)da vlizešb v(b) 
gr(a)d' naideš' $\operatorname{cr}(\hat{e}) \mathrm{k}(\mathrm{a}) \mathrm{vb} \mathrm{s}(\mathrm{ve})$ te $\mathrm{m}(\mathrm{a})$ rie $\cdot \mathrm{i}$ êkim' vb nei roena $\mathrm{n}(\mathrm{a})$ ša gospoê - i naprid' e(stb) kaluža g'di is'celi is(u)h(rbst)' nemoĉnika · Mini cr(ê)k(a)vb naidešb hramb pilatov' · i naprid' irudova · I poprid' e mêsto mês'to [sic!] k'di b(la)ž(e)na m(a)riê utak'nu g(ospo)d(i)na kada kr(i)žb nesiše · trudan' i unevolenь - i pade ka za mr'tva i naprid'e lukb v' kom' sta dva kamika bêla na kiû $g($ ospo $) d(i) n ь$ poči trudan' bude $\cdot \mathrm{i}$ tu bê položens križb na simuna $\cdot \mathbf{i}$ tu e(stb) mesto g'di is(u)h(rbst)b r(e)če deĉeram' er(u)s(o)l(i)m(s)kim' ne imate me [sic!] plakati nad' mnu $\cdot$ I tu hram' iûdi pred'av'ca · I tu položi s(ve)ta elena k'rižb na mrtv'ca i bi živ' · ot er(u)s(o)l(i)ma do vit'leoma mile ·g· [=4] i e(stb) pols puti s(ve)ti iliê i meû cr(ê)kvu i vitlêomomb e(stb) grobs rahilin' Stran' puta · v' vitlêome e(stb) s(ve)ta m(a)riê i v nei e roens $\mathrm{sp}(\mathrm{a}) \mathrm{s}(\mathrm{ite}) \mathrm{l}^{\prime} \cdot \mathbf{I}$ esu ês'li gdi bê pol(16rb) [oženь ...] e(stb) grob' s(ve)t(a)go eronima · i e(stb) peĉ gdi e stal' i druga peĉs kdi bi poleženo [sic!] veliko s(ve)tihь telesь - I e(stb) edna mila ot v(i)tlêoma na vstokb k'di se anĵ(e)lı pokaza pastiremb ot er(u)s(o)l(i)ma i tu grobs k'di is(u)h(rbst)b v'skr(ê)si lazara · i naprid' e kami kadi mar'ta pride k' $\mathrm{g}(\mathrm{o}) \mathrm{sp}(\mathrm{o}) \mathrm{du}$ rekuĉi g(ospod)i ako bi ti sade bil' ne bi brat' moi umr(b)lb · mêsto k'di mar'ta služaše g(o)spodinu i magdalı tu e(stb) ot bitanie do er(u)s(o)l(i)ma do êrd(a)na 'b· $[=2]$ mili i b'liz' e(stb) rêka ed'na s(ve)ti iv(a)nь i e(stb) zvanь gal'gala gdi s(i)ni iz(drai)l(e)vi minuše êrdanь i položiše bï [=12] kamika ke vzeše ot rêki ed'na mila e(stb) Mêsto k'di bi

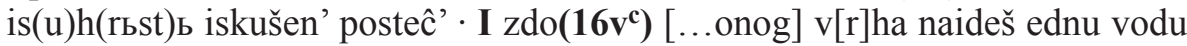
ku osladi pro(ro)kb elisei · ot er(u)s(o)l(i)ma doli kapole bï· [=12] mili · I v depokali ed(a)nь grad' sikarii e(stb) z(a)stavlenь meû dvima vrhoma ed(a)n' e garazimь a drugi ebalı i bl(i)zu vlazeĉi v gr(a)d ot strani er(u)s(o)l(i)ma e(stb) ed(a)n studenacь narečeni êkovalı na kom govori i(su)sь samaritanê ot kapole suprotiv' aciû [dubitanter!] d'vi milie vladanû imenemb sabastemь - I prid'ne vrême bi zvano samariê $\cdot i$ ondi sta $\cdot \mathbf{b} \cdot[=2] \operatorname{cr}(\hat{e}) \mathrm{kvi} \mathrm{s}(\mathrm{ve}) \mathrm{t}(\mathrm{a}) \mathrm{go}$ ivana edna na sl'nčb zapad' i v n(e)i mu e gl(a)va usičena i drže û h(rbst)bêne a v' drugoi bi položen' i drže û sracini · ot er(u)s(o)l(i)ma 'b [ [=2] mili ot zapada mêsto v kom' se rodi (16 $\left.\mathbf{1 6 v}^{\mathbf{d}}\right)$ iv'nb $\mathrm{kr}(\mathrm{b}) \mathrm{s}(\mathrm{ti}) \mathrm{t}(\mathrm{e}) \mathrm{l}^{\prime} \cdot \mathbf{I}$ tim putem' naideš' kr(i)ža s(ve)t(a)go cr(ê)k(a)vb i tu e treno i sičeno drivo s(veta)go križa na kom' raspetı bi is(u)h(rbst)' i meû cr(ê)kvu i g'radom' e(stb) edna peĉ' l'vova

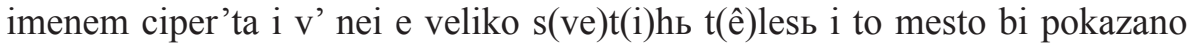

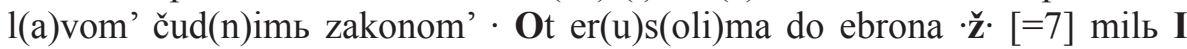
v' eb(ro)ni su ova mesta · Prvo peĉ' dupla in'di e pokopan' avram' i isakb i êkov' i s' svoimi ženami e sara reveka liê · I ne puĉaû v'nutar h(rbst)bênb · I ondi b'lizu mêsto gdi leži c(êsa)rı damasinuš' · in'di bi adam stvoren' blizu ebr(o)nu e edna peĉ́'v ko(i) e ad(a)m' stal' ·r' [=100] lêt' za žalost' s(i)na avela - I oĉe ednu milu z' eb'rona greduĉb v' er(u)s(o)l(i)mb est' edna dr(u)ga ka se

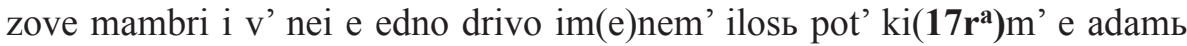
stal' $\cdot$ veĉe $\cdot d \cdot[=5]$ tisuê' $1(\hat{e})$ tb · 


\section{KRATICE}

BAV - Biblioteca Apostolica Vaticana (Rim)

BL - Bodleian Library (Oxford)

CPG - Clavis Patrum Graecorum

CSEL - Corpus Scriptorum Ecclesiasticorum Latinorum

GIM - Gosudarstvennyj istoričeskij muzej (Moskva)

HAZU - Hrvatska akademija znanosti i umjetnosti (Zagreb)

JAZU - Jugoslavenska akademija znanosti i umjetnosti (Zagreb)

NSK - Nacionalna i sveučilišna knjižnica (Zagreb)

NUK - Narodna in univerzitetna knjižnica (Ljubljana)

PSHK - Pet stoljeća hrvatske književnosti

RNB - Rosijskaja nacional'naja biblioteka (Sankt-Peterburg)

SHK - Stoljeća hrvatske književnosti

\section{IZVOR}

CVinod - Vinodolski zbornik. Zagreb: Arhiv HAZU, sign. III a 15.

\section{LITERATURA}

AUERBACH, E. 1993. Literary Language and Its Public in Late Latin Antiquity and in the Middle Ages. Trans. by R. Manheim. New Jersey: Princeton University Press.

BADURINA-STIPČEVIĆ, V. 2011. Jagićeva izdanja hrvatskih srednjovjekovnih književnih tekstova. Slovo 61: 1-14.

BADURINA STIPČEVIĆ, V. 2013. Hrvatska srednjovjekovna proza I. Legende i romani. Zagreb: Matica hrvatska. [=SHK 115]

BADURINA STIPČEVIĆ, V. 2014. Mjesto Kristove Muke - Golgota u hrvatskoglagoljskim biblijskim prijevodima. A. Zaradija Kiš, M. Žagar (ur.). Glagoljaška Muka Kristova: odabrane kulturološko-filološke studije. Zagreb - Pazin: Hrvatska sveučilišna naklada; Institut za etnologiju i folkloristiku; Državni arhiv u Pazinu, 11-22.

BAERT, B. 2004. A Heritage of Holly Wood. The Legend of the True Cross in Text and Image. Trans. by L. Preedy. Leiden - Boston: Brill.

BEEBE, K. 2014. Pilgrim and Preacher. The Audiences and Observant Spirituality of Friar Felix Fabri (1437/8-1502). Oxford: Oxford University Press.

BELAMARIĆ, J. 2014. The Holy Portolano. The Sacred Geography of Navigation along the Dalmatian coast in the Middle Ages. M. Bacci, M. Rohde (eds.). The Holy Portolano: The Sacred Geography of Navigation in the Middle Ages, Fribourg Colloquium 2013. Le Portulan Sacre: Le géographie religieuse de la navigation au Moyen Âge, Colloque Fribourgeois 2013. Berlin: De Gruyter, 159-183. 
BITI, V. 2000. Pojmovnik suvremene književne i kulturne teorije. Zagreb: Matica hrvatska. BLAŽEVIĆ, Z. 2014. Historijska znanost i izazovi lingvističkog i kulturnog obrata. Prevođenje povijesti. Teorijski obrati i suvremena historijska znanost. Zagreb: Srednja Europa, 25-48.

BRATULIĆ, J. 1978. Istarski razvod. Studija i tekst. Pula: Čakavski sabor.

BREFELD, J. 1985. An Account of a Pilgrimage to Jerusalem. Zeitschrift des Deutschen Palästina-Vereins (1953-) 101/2: 134-155.

BREFELD, J. 1994. A Guidebook for the Jerusalem Pilgrimage in the Late Middle Ages: A Case for Computer-Aided Textual Criticism. Hilversum: Verloren.

BRKOVIĆ, I. 2013. Književni svjetovi u svjetlu prostornoga obrata. Umjetnost riječi 57/1-2: 115-138.

BUNČUGA, B.; J. FARIČIĆ; P. KERO. 2016. Riznica glagoljaške kulture i hrvatske pismenosti otoka Rave. Knjiga 3. Fatevićev zbornik duhovnog štiva 1617. Zadar: Sveučilište u Zadru - Stalna izložba crkvene umjetnosti. [=Monumenta glagolitica Archidiocesis Iadertinae 19/3]

BURCHARD OF MOUNT SION. 1896. A Description of the Holy Land by Burchard of Mount Sion. Trans. by A. Stewart. London: Palestine Pilgrims' Text Society.

BURKE, P. 2010. The Cultural History of the Travelogue. Przeglad Historyczny 101/1: $1-11$.

BUSBY, K; C. KLEINHENZ. 2015. Medieval French and Italian literature: towards a manuscript history. M. Johnston, M. van Dussen (eds.). The Medieval Manuscript Book: Cultural Approaches. Cambridge: Cambridge University Press, 215-242.

BUTOR, M. 1972. Le voyage et l'écriture. Romantisme 2/4: 4-19.

CAMPOPIANO, M. 2012. Islam, Jews and Eastern Christianity in Late Medieval Pilgrims' Guidebooks: Some Examples from the Franciscan Convent of Mount Sion. Al-Masāq: Islam and the Medieval Mediterranean 24/1: 75-89.

CARRUTHERS, M. 1998. The Craft of Thought. Meditation, Rhetoric, and the Making of Images, 400-1200. Cambridge: Cambridge University Press.

CARRUTHERS, M. 2008. The Book of Memory. A Study of Memory in Medieval Culture. Second edition. Cambridge: Cambridge University Press.

DAMJANOVIĆ, S. 1995. Glagolitica kajkaviana. Jazik otačaski. Zagreb: Matica hrvatska, 63-80.

DAMJANOVIĆ, S. 2002. Slovo iskona. Staroslavenska/starohrvatska čitanka. Zagreb: Matica hrvatska.

DAMJANOVIĆ, S. 2008. Glagolitica kajkaviana. Jezik hrvatskih glagoljaša. Zagreb: Matica hrvatska, 129-180.

DEROSSI, J. 1975. Korizmenjak Broza Kolunića i Misal 1483. Marulić 8/1: 26-34.

DORNINGER, M. E. 2010. Travelogues. A. Classen (ed.). Handbook of Medieval Studies: Terms - Methods - Trends. Volume 3. Berlin - New York: De Gruyter, 2102-2117.

DORNINGER, M. E. 2014. Memory and Representation of Jerusalem in Medieval and Early Modern Pilgrimage Reports. B. Kühnel, G. Noga-Banai, H. Vorholt (eds.), Visual Constructs of Jerusalem. Turnhout: Brepols, 421-428. 
DUDA, D. 1998. Priča i putovanje. Hrvatski romantičarski putopis kao pripovjedni žanr. Zagreb: Matica hrvatska.

DUDA, D. 2012. Kultura putovanja. Uvod u književnu iterologiju. Zagreb: Naklada Ljevak.

DÜRRIGL, M.-A. 2002. O hrvatskoglagoljskim srednjovjekovnim egzemplima. Umjetnost riječi 56/3: 121-137.

DÜRRIGL, M.-A. 2006. Putovanje kao zaplet dvaju hrvatskoglagoljskih pripovjednih tekstova. Umjetnost riječi 50/4: 287-304.

DÜRRIGL, M.-A. 2006.-2007. Naslovi hrvatskoglagoljskih tekstova: neka otvorena genološka pitanja. Slovo 56-57: 131-140.

DÜRRIGL, M.-A. 2007. Čti razumno i lipo. Ogledi o hrvatskoglagoljskoj srednjovjekovnoj književnosti. Zagreb: Hrvatska sveučilišna naklada.

DÜRRIGL, M.-A. 2013. Hrvatska srednjovjekovna proza II. Apokrifi, vizije, prenja, Marijini mirakuli. Zagreb: Matica hrvatska. [=SHK 116]

DÜRRIGL, M.-A. 2016. Eshatološke vizije u hrvatskoglagoljskoj književnosti. Poetičke $i$ žanrovske značajke. Zagreb: Hrvatska sveučilišna naklada.

ELSNER, J. 2000. The Itinerarium Burdigalense: Politics and Salvation in the Geography of Constantine's Empire. The Journal of Roman Studies 90: 181-195.

FALIŠEVAC, D. 1980. Hrvatska srednjovjekovna proza. Književnopovijesne i poetičke osobine. Zagreb: Hrvatsko filološko društvo.

FALLON, N. 2009. The Cross as Tree: The Wood-of-the-Cross Legends in Middle English and Latin Texts in Medieval England. Toronto: University of Toronto. [PhD thesis]

GAUNT, S. 1995. Gender and Genre in Medieval French Literature. Cambridge: Cambridge University Press.

GERVASIUS VON TILBURY. 1856. Otia imperalia. Hrsg. von F. Liebrecht. Hannover: Carl Rümpler.

GEYER, P. 1898. Itinera Hierosolymitana. Saecvli IIII-VIII. Praga - Vindobona - Lipsia: Tempsky - Freytag.

GINZBURG, C. 1980. The Cheese and the Worms. The Cosmos of a Sixteenth-Century Miller. Trans. by J. Tedeschi and A. Tedeschi. Baltimore: The Johns Hopkins University Press.

GRACIOTTI, S. 2014. La Dalmazia e l'Adriatico dei pellegrini "veneziani« in Terrasanta (secoli XIV-XVI). Studio e testi, con un' appendice di Lorenzo Lozzi Gallo. Roma - Venezia: Società Dalmata di Storia Patria; La Musa Talìa Editrice.

GRMAČA, D. 2015. Nevolje s tijelom. Alegorija putovanja od Bunića do Barakovića. Zagreb: Matica hrvatska.

GUMBERT, J. P. 2004. Codicological Units: Towards a Terminology for the Stratigraphy of the Non-Homogenous Codex. Segno e testo 2: 17-42.

HALBWACHS, M. 1992. On Collective Memory. Ed. and trans. by L. A. Coser. Chicago - London: University of Chicago Press.

HARVEY, P. D. A. 1996. Cartography and Its Written Sources. F. A. C. Mantello, A. G. Rigg (eds.), Medieval Latin. An Introduction and Bibliographical Guide. Washington: The Catholic University of America, 388-394.

HERCIGONJA, E. 1967. Glagoljska verzija pune redakcije Pavlove apokalipse iz Oxfordskoga kodeksa Ms. Can. lit. 414. Radovi Staroslavenskog zavoda 6: 209-255. 
HERCIGONJA, E. 1975. Srednjovjekovna književnost. Zagreb: Liber - Mladost. [=Povijest hrvatske književnosti. Knjiga 2]

HERCIGONJA, E. 1983. Kajkavski elementi u jeziku glagoljaške književnosti 15. i 16. stoljeća. Nad iskonom hrvatske knjige. Rasprave o hrvatskom srednjovjekovlju. Zagreb: Sveučilišna naklada Liber, 303-385.

HERCIGONJA, E. 2006. Tropismena i trojezična kultura hrvatskoga srednjovjekovlja [2. izdanje]. Zagreb: Matica hrvatska.

HERCIGONJA, E. 2009. Tisućljeće hrvatskoga glagoljaštva. Zagreb: Hrvatska sveučilišna naklada.

HILHORST, A. 2007. Ager Damascenus: Views on the Place of Adam's Creation. Warszawskie Studia Teologiczne 20/2: 131-144.

IACOBUS VERONENSIS. [s.a.]. Liber peregrinationis. Archivio della latinità italiana del Medioevo. http://www.alim.dfll.univr.it/alim/letteratura.nsf/(volumiID)/599CAFBADFACA802C1256D3A00334D2F (24. kolovoza 2017.).

IBLER, M. 2012. Borgiano illirico 5-6. Prilog srednjovjekovnoj glagoljaškoj baštini Gacke. H. Gračanin, Ž. Holjevac (ur.). Gacka u srednjem vijeku. Zbornik radova. Zagreb - Otočac: Institut društvenih znanosti Ivo Pilar, Područni centar Gospić, 245-253.

IVANČEVIĆ, R. 1979. Uvod u ikonologiju. A. Badurina (ur.). Leksikon ikonografije, liturgike i simbolike zapadnog kršćanstva. Zagreb: Sveučilišna naklada Liber; Kršćanska sadašnjost; Institut za povijest umjetnosti, 13-82.

IVŠIĆ, S. 1949. Prijevod »Lucidara« Honorija Augustodunensisa u prijepisu Gverina Tihića iz godine 1533. Starine 42: 105-259.

JACQUES DE VITRY. 1896. The History of Jerusalem. A. D. 1180. Trans. by A. Stewart. London: Palestine Pilgrims' Text Society.

JAGIĆ, V. 1866. Priměri starohèrvatskoga jezika iz glagolskih i cirilskih književnih starinah, sastavljeni za sedmi i osmi gimnazijalni razred. Dio drugi. Uvod i priméri starohèrvatski. Zagreb: Brzotiskom Antuna Jakića.

JAGIĆ, V. 1868. Prilozi k historiji književnosti naroda hrvatskoga i srbskoga. Arkiv za povjestnicu jugoslavensku 9: 65-151.

JERUZALEMSKA BIBLIJA. 2001. Jeruzalemska Biblija. Stari i Novi zavjet s uvodima i bilješkama iz La Bible de Jérusalem. Prir. A. Rebić, J. Fućak, B. Duda. Zagreb: Kršćanska sadašnjost.

JOHN POLONER. 1894. John Poloner's Description of the Holy Land (circa 1421 A.D.). Trans. by A. Stewart. London: Palestine Pilgrims' Text Society.

JURKOVIĆ, I. 2013. U potrazi za slavom mučeništva? Sv. Nikola Tavelić i martirski pokret u Córdobi - razlike i sličnosti. Croatica Christiana Periodica 72: 1-19.

KAPETANOVIĆ, A. 2010. Lucidarij iz Petrisova zbornika. Građa za povijest književnosti hrvatske 37: 3-33.

KAPETANOVIĆ, A. 2016. Jezični značaj varijantnih tekstova u Vinodolskom zborniku s početka 15. stoljeća. T. Kuštović, M. Žagar (ur.), Meandrima hrvatskoga glagoljaštva. Zbornik posvećen akademiku Stjepanu Damjanoviću o 70. rođendanu. Zagreb: Hrvatska sveučilišna naklada, 213-218. 
KOLANOVIĆ, J. 1982. Prilog povijesti šibenskih hodočašća u kasnom srednjem vijeku. Croatica Christiana Periodica 9: 13-36.

KOMBOL, M. 1961. Povijest hrvatske književnosti do narodnog preporoda. [2. izdanje]. Zagreb: Matica hrvatska.

KONDRATENKO, K. O. 2013. »Podorož do Jerusalimu roku 1752« Ja. Pletikosi u konteksti stanovlennja žanru podorožnogo narisu u horvatskij literaturi. V. P. Kazarin (red.). Svitova literatura na perehresti kuljtur i civilizacij. Zbirnik naukovih prac. Vipusk 7. Častina 1. Simferopolj: Krimskij Arhiv, 91-96.

KRAMARIĆ, M. 2015. Bohemizmi u Zrcalu člověčaskago spasenja (1445.) u kontekstu starohrvatskih prijevoda sa staročeškoga jezika. Rijeka: Sveučilište u Rijeci. [Doktorska disertacija]

KRASIĆ, S. 2001. Opis hrvatske jadranske obale u putopisima švicarskog dominikanca Feliksa Fabrija (Schmida) iz 1480. i 1483/84. godine. Anali Zavoda za povijesne znanosti HAZU u Dubrovniku 39: 133-216.

KRUHEK, M. 2009. Bernardin Frankopan krčki, modruški i senjski knez - posljednji modruški Europejac hrvatskoga srednjovjekovlja, 1453.-1529. Modruški zbornik 3: $187-235$.

KUŽIĆ, K. 2013. Hrvatska obala u putopisima njemačkih hodočasnika XIV. - XVIII. st. Opora - vinorodna-kršćanska. Split: Književni krug.

LADIĆ, Z. 1993. Prilog proučavanju hodočašćenja iz Zadra u drugoj polovici 14. stoljeća. Croatica Christiana Periodica 32: 17-31.

LADIĆ, Z. 1999. Odjek pada tvrđave Accon 1291. g. u Hrvatskoj (O križarskoj vojni kao vidu hodočašća). Zbornik Odsjeka za povijesne znanosti Zavoda za povijesne $i$ društvene znanosti HAZU 16: 43-56.

LADIĆ, Z. 2005. O razlozima sastavljanja kasnosrednjovjekovnih dalmatinskih oporuka. N. Budak (ur.). Raukarov zbornik. Zbornik u čast Tomislava Raukara. Zagreb: FF Press, 607-623.

LADIĆ, Z. 2006. Ponukani pobožnošću i znatiželjom. O kasnosrednjovjekovnim rapskim hodočasnicima. Kolo 4: 262-271.

LADIĆ, Z. 2014. Medieval Pilgrims from the Eastern Adriatic Coast to Terra Sancta and Jerusalem. A. Trono, M. L. Imperiale, G. Marella (cur.). In viaggio verso Gerusalemme. Culture, economie e territori. Lecce: Mario Congedo Editore, 95-111.

LADIĆ, Z. 2015. Hodočašća kao izraz pobožnosti stanovnika kasnosrednjovjekovne porečke komune. Histria 5: 15-41.

MARINO SANUDO TORSELLO. 2011. The Book of the Secrets of the Faithfull of the Cross. Liber Secretorum Fidelium Crucis. Trans. by P. Lock. Farnham - Burlington: Ashgate.

McNAMER, S. 2010. Affective Meditation and the Invention of Medieval Compassion. Philadelphia: University of Pennsylvania Press.

MIHALJEVIĆ, M. 2011. Položaj crkvenoslavenskoga jezika u hrvatskoj srednjovjekovnoj kulturi. I. Velev, A. Girevski, L. Makarijoska, I. Piperkoski, K. Mokrova (red.). Zbornik na trudovi od Međunarodniot naučen sobir »Sveti Naum Ohridski i sloven- 
skata duhovna, kulturna i pismena tradicija« (organiziran po povod 1100-godišninata od smrtta na sv. Naum Ohridski). Ohrid, 4-7 noemvri. Skopje: Univerzitet Sv. Kiril i Metodij, 229-238.

MIHALJEVIĆ, M.; J. VINCE. 2012. Jezik hrvatskoglagoljskih Pazinskih fragmenata. Zagreb: Hrvatska sveučilišna naklada - Državni arhiv u Pazinu - Staroslavenski institut.

MILČETIĆ, I. 1911. Hrvatska glagolska bibliografija. I. dio: opisi rukopisâ. Zagreb: JAZU. [=Starine 33]

MILIČIĆ, I. 2010. Teoretičari, hodočasnici, činovnici: tri vrste renesansnih putopisnih tekstova. Povijesni prilozi 38: 43-69.

MORRIS, C. 2005. The Sepulchre of Christ and the Medieval West. From the Beginning to 1600. Oxford: Oxford University Press.

MUSSIES, G. 1997. Jesus and 'Sidon' in Matthew 15/Mark 7. Bijdragen, tijdschrift voor filosofie en theologie 58: 264-278.

NAZOR, A. 2001. Prijevod »Lucidara« Honorija Augustodunensisa u glagoljskom prijepisu. Godišnik na Sofijskija universitet »Sv. Kliment Ohridski«. Centâr za slavjanovizantijski proučavanija »Prof. Ivan Dujčev« 89 (8): 89-112.

NOVAK, S. P. 1996. Povijest hrvatske književnosti. Od početaka do Krbavske bitke. I. knjiga. Zagreb: Antibarbarus.

PARKER, S. T. 1975. The Decapolis Reviewed. Journal of Biblical Literature 94/3: 437-441.

PAVLOVIĆ, C. 2010. Putovanje k Jeruzolimu god. 1752. - Uspostava putopisnog žanra u hrvatskoj književnosti. Dani hvarskog kazališta. Građa i rasprave o hrvatskoj književnosti i kazalištu 36: 139-158.

PEARSALL, D. 2005. The Whole Book: Late Medieval English Manuscript Miscellanies and their Modern Interpreters. S. Kelly; J. J. Thompson (eds.). Imagining the Book. Turnhout: Brepols, 17-29.

PEDERIN, I. 2007. Hrvatski putopis. Rijeka: Maveda.

PETROVIĆ, I. 1972. Bogorodičina čudesa u Ivančićevu zborniku, hrvatskoglagoljskom spomeniku 14/15. st. Radovi Staroslavenskog instituta 7: 123-210.

PIVČEVIĆ, E. 1988. Jedno svjedočanstvo o hrvatskim gradovima iz godine 1486. Rad JAZU 429: 185-195.

PLEJIĆ POJE, L. 2010. Tko doma ne sidi, a tko sidi? Tema putovanja i ženski likovi u ranonovovjekovnoj književnosti. Dani hvarskog kazališta. Građa i rasprave o hrvatskoj književnosti i kazalištu 36: 72-87.

RADOŠEVIĆ, A. 2016. Kajkavizmi u hrvatskome prijevodu Dispula Johannesa Herolta $(\dagger$ 1468.). Rasprave: Časopis Instituta za hrvatski jezik i jezikoslovlje 42/1: 245-266.

REBIĆ, A. 1984. Hodočašća u Svetu Zemlju u posljednjih 100 godina. Bogoslovska smotra 54/4: 553-560.

REINHART, J. 2015. Hrvatskoglagoljsko Čtenie ot zlih žen, njegov staroslavenski i grčki izvornik (CPG 7746). V. Badurina Stipčević, S. Požar, F. Velčić (ur.). Hrvatsko glagoljaštvo u europskom okružju. Zbornik radova Međunarodnoga znanstvenoga skupa povodom 110. obljetnice Staroslavenske akademije i 60. obljetnice Staroslavenskoga instituta, Krk, 5. i 6. listopada 2012. Zagreb: Staroslavenski institut, 341-360. 
REŠETAR, M. 1926. Libro od mnozijeh razloga. Dubrovački ćirilski zbornik od g. 1520. Sremski Karlovci: Srpska kraljevska akademija. [=Zbornik za istoriju, jezik i književnost srpskog naroda. Prvo odeljenje. Knj 15]

RICHARD, J. 1996. Travel Literature. Translated from French by G. E. Gignras. F. A. C. Mantello, A. G. Rigg (eds.). Medieval Latin. An Introduction and Bibliographical Guide. Washington: The Catholic University of America, 682-687.

RJEČNIK. 2000. Rječnik crkvenoslavenskoga jezika hrvatske redakcije. I. svezak: A$V R \hat{E} D b$. Zagreb: Staroslavenski institut.

RUDY, K. M. 2000. A Guide To Mental Pilgrimage: Paris, Bibliothèque de L'Arsenal Ms. 212. Zeitschrift für Kunstgeschichte 63: 494-515.

RUDY, K. M. 2014. Virtual Pilgrimage through the Jerusalem Cityscape. B. Kühnel, G. Noga-Banai, H. Vorholt (eds.). Visual Constructs of Jerusalem. Turnhout: Brepols, 381-393.

RUNJE, P. 1997. Hrvatski jezik i hodočasnici (u srednjem vijeku). S. Damjanović (ur.). Prvi hrvatski slavistički kongres. Zbornik radova 1. Zagreb: Hrvatsko filološko društvo, 503-510.

RUNJE, P. 2012. Hrvatski franjevci trećoredci hodočasnici u srednjem vijeku. Prema izvorima II. Rasprave i članci o hrvatskim franjevcima trećoredcima glagoljašima. Krk - Zagreb: Povijesno društvo otoka Krka; Provincijalat franjevaca trećoredaca glagoljaša, 75-78.

SAMBUNJAK, S. 2001. Tkonski zbornik: hrvatskoglagoljski tekstovi iz 16. stoljeća. Tkon: Općina Tkon.

SCHNEIDER, I. 2002. O odnosu stvarnosti i fikcije u putopisima i etnografskim izvorima: prilog hermeneutici tuđine. Narodna umjetnost 39/2: 159-174.

STROHAL, R. 1916. Cvêt vsake mudrosti. Najstarije hrvatsko umjetno sačuvano književno djelo iz 14. vijeka. Zagreb: Tisak C. Albrechta.

STROHAL, R. 1917. Stare hrvatske apokrifne priče i legende. Bjelovar: Lavoslav Weiss.

ŠTEFANIĆ, V. 1960. Glagoljski rukopisi otoka Krka. Zagreb: JAZU.

ŠTEFANIĆ, V. 1969.a. Glagoljski rukopisi Jugoslavenske akademije. I. dio: uvod, Biblija, apokrifi i legende, liturgijski tekstovi, egzorcizmi i zapisi, molitvenici, teologija, crkveni govori (homiletika), pjesme. Zagreb: JAZU.

ŠTEFANIĆ, V. 1969.b. Hrvatska pismenost i književnost srednjeg vijeka. V. Štefanić, B. Grabar, A. Nazor, M. Pantelić (prir.). Hrvatska književnost srednjega vijeka. Zagreb: Matica hrvatska - Zora, 3-68. [=PSHK 1]

ŠTEFANIĆ, V. 1970. Glagoljski rukopisi Jugoslavenske akademije. II. dio: zbornici različitog sadržaja, regule i statuti, registri, varia, indeksi, album slika. Zagreb: JAZU.

ŠTEFANIĆ, V.; B. GRABAR; A. NAZOR; M. PANTELIĆ. 1969. Hrvatska književnost srednjega vijeka. Zagreb: Matica hrvatska; Zora. [=PSHK 1]

TATARIN, M. 2003. Bludnica i svetica. Starohrvatska legenda o Mariji Egipćanki. Zagreb: Naklada Ljevak.

TATARIN, M. 2010. Putovanja Mande Krkarke. Dani hvarskog kazališta. Građa i rasprave o hrvatskoj književnosti i kazalištu 36: 47-71. 
TURKALJ, L. 2006-2007. Život Adama i Eve u Žgombićevu i Fatevićevu zborniku. Slovo 56-57: 579-593.

VALJAVAC, M. 1892. Kolunićev zbornik. Hrvatski glagolski rukopis od godine 1486. Zagreb: JAZU. [=Djela JAZU 12]

VIALOVA, S. O. 2016. Glagoličeskij sbornik XV v. Rossijskaja nacional'naja biblioteka. Sobranie Ivana Berčiča, f. 67, Berčič № 5. Glagoljski zbornik 15. st. Ruska nacionalna biblioteka. Zbirka Ivana Berčića, f. 67, Berčić br. 5. Knjiga 2. Zadar: Sveučilište u Zadru - Stalna izložba crkvene umjetnosti. [=Monumenta glagolitica Archidioecesis Iadertinae 20/2]

VIDMAROVIĆ, Đ. 2010. Prilog upoznavanju hrvatskih putopisa po Svetoj Zemlji. Portal hrvatskoga kulturnog vijeća. http:/www.hkv.hr/izdvojeno/komentari/dvidmarovic/6127-drijelo-crnih-lista-343.html (2. listopada 2016.).

VUČKOVIĆ, J. 2012. Emocije u hrvatskim srednjovjekovnim prikazivanjima muke i pobuđivanje suosjećanja. A. Kapetanović (ur.). Poj željno! Iskazivanje i poimanje emocija u hrvatskoj pisanoj kulturi srednjega i ranoga novoga vijeka. Zagreb: Institut za hrvatski jezik i jezikoslovlje, 117-149.

VUČKOVIĆ, J. 2017. Komentar: fantomski hrvatskoglagoljski bestijarij. Old Croatian Literature. https://oldcroatianliterature.wordpress.com/2017/10/05/komentar-fantomski-hrvatskoglagoljski-bestijarij/ (5. listopada 2017.).

VUGDELIJA, M. 1993. Patnja i bol u svjetlu Biblije i ljudskog iskustva. Zagreb - Makarska: Franjevačka visoka bogoslovija.

WEBB, D. 1999. Pilgrims and the Pilgrimage in the Medieval West. London - New York: I. B. Tauris.

WEBB, D. 2002. Medieval European Pilgrimage, c.700-c.1500. Houndmills: Palgrave.

WEIMAR, P. 1997. Dekapolis. A. Grabner-Haider (ur.). Praktični biblijski leksikon. Prev. B. Lujić, L. Fišić. Zagreb: Kršćanska sadašnjost, 53.

WESTREM, S. D. 1997. Josephie Brefeld, A Guidebook for the Jerusalem Pilgrimage in the Late Middle Ages: A Case for Computer-Aided Textual Criticism. (Middeleeuwse Studies en Bronnen, 40.) Hilversum, Neth.: Verloren, 1994. Paper. Pp. 243: tables, graphs, black-and-white illustrations. Hfl 45. Speculum 72/1: 116-119.

WRIGHT, J. K. 1925. The Geographical Lore of the Time of the Crusades. A Study in the History of Medieval Science and Tradition in Western Europe. New York: American Geographical Society.

ZARADIJA KIŠ, A. 2015.a. Bestijarijski pabirci u Akademijinim rukopisima HAZU IV a 48 i HAZU III a 15. V. Badurina Stipčević, S. Požar, F. Velčić (ur.). Hrvatsko glagoljaštvo u europskom okružju. Zbornik radova Međunarodnoga znanstvenoga skupa povodom 110. obljetnice Staroslavenske akademije i 60. obljetnice Staroslavenskoga instituta, Krk, 5. i 6. listopada 2012. Zagreb: Staroslavenski institut, 413-446.

ZARADIJA KIŠ, A. 2015.b. Tragom bestijarija kroz Cvêt ot kreposti u Tkonskom zborniku. Zadarski filološki dani 5: 125-152.

ZISSU, B; A. S. TENDLER. 2011. The Kidron Valley Tombs in the Byzantine Period: A Reconsideration. E. Baruch, A. Levy-Reifer, A. Faust (eds.). New Studies on Jerusalem. Volume 17. Ramat-Gan: Ingeborg Rennert Center for Jerusalem Studies, $7 *$ _43*.

ŽAGAR, M. 2007. Grafolingvistika srednjovjekovnih tekstova. Zagreb: Matica hrvatska. 


\section{Summary}

Josip Vučković

\section{MEDIEVAL ITINERARY AROUND THE HOLY LAND IN THE VINODOL MISCELLANY}

This article presents a literary and historical analysis of the text ot er(u)s(o)l(i)ma i groba $b(o) z ̌ i e ̂ ́ c t$ (enie) [The reading on Jerusalem and God's Sepulchre] which is preserved in a late medieval Glagolitic codex known as the Vinodol miscellany (Zagreb: Archives of the Croatian Academy of Sciences and Arts, sign. III a 15). In addition it contains the first edition of the source. The text is identified as a member of the itineraria genre and it is the only known medieval itinerary in the Holy Land written in the Croatian language. While the direct source of the Croatian texts has not been found, a few idiosyncratic toponyms point to the conclusion that the Croatian writer was using a Latin or a Romance source. The itinerary describes the pilgrimage from the Holy Sepulchre in Jerusalem to Hebron, where the creation of Adam was to be commemorated. In this article, I argue that the pilgrims' progression through the sites could have been envisaged as the commemoration of the history of salvation in a reverse order. Given that the text refers to the contemporary Muslim presence in the Holy Land only once, it was unlikely to be intended as a practical guide for a real pilgrimage. The avoidance of the references to the Muslim presence allow for an interpretation of the itinerary as an instructive text which was promoting the western construct of the Holy Land as a sacred area to which the Christians have the exclusive right. A further support for the conclusion that the text was not a practical guide comes from the codicological placement of the itinerary between texts which were written for the purpose of religious instruction. Apart from serving the purpose of Christian memory building, the itinerary could have also been used as a script for a meditative religious devotion in the form of a virtual pilgrimage.

Keyw ords: Vinodol miscellany, medieval itinerary, Croatian Glagolitic literature, pilgrimage, virtual pilgrimage, medieval Jerusalem, Holy Land, collective memory, iterology 